\title{
A New Witness to the Fayyūmic Version of First Corinthians (P.MorganLib. 265). Part II: Notes on its Text-Critical Value, with an Edition of the Coptic Text
}

\author{
Ivan Miroshnikov
}

Swedish Collegium for Advanced Study, Linneanum, Thunbergsvägen 2, 75238 Uppsala, Sweden; Centre for Egyptological Studies, Russian Academy of Sciences, 29-8 Leninsky Avenue, Moscow, 119071, Russian Federation

Email: ivan.miroshnikov@gmail.com

\begin{abstract}
This is the second part of a two-part article focused on a fragmentary parchment codex, whose three extant leaves, designated in Leo Depuydt's catalogue as P.MorganLib. 265, are housed at the Morgan Library \& Museum in New York. These fragments bear witness to 1 Cor 2.12-3.18; 7.16-30; $15.3-30$ in the 'classical' variety of Fayyūmic Coptic (dialect F5). The first part of this article was published in NTS 68 (2022) 89-104. In the second part, I discuss the witnesses to the Fayyūmic version (fa) of First Corinthians, the relationship between fa and the Bohairic version (bo), and the text-critical value of the variant readings attested in P.MorganLib. 265. This is followed by the editio princeps of the manuscript, notes on the Coptic text, an English translation and images.
\end{abstract}

Keywords: Coptic New Testament; Fayyūmic Coptic; First Letter to the Corinthians; textual criticism

Having discussed various features of P.MorganLib. 265 as a manuscript, I am now going to discuss the Fayyūmic text of First Corinthians, of which this manuscript is a witness. I will first survey the other Fayyūmic manuscripts of First Corinthians and suggest that they all bear witness to the same version ( $\mathrm{fa}$ ), then analyse the relationship between fa, the medieval Bohairic version (bo) and the text of codex $C$, and finally discuss the value of the newly published witness to fa for the history of the Greek text of First Corinthians.

\section{Version}

To the best of my knowledge, in addition to P.MorganLib. 265, there are five other witnesses to First Corinthians in Fayyümic; four of them are written in dialect F5, one in dialect F4. Of these five manuscripts, two have parallel text with P.MorganLib. 265:

- P.MorganLib. 268. A fragmentary leaf from a codex, comprising 1 Cor 14.25-7, 32-5; 15.1-4, 9-12. Despite the fact that this is the only witness to the Fayyumic First Corinthians on papyrus, its palaeography (the manuscript is written in bimodular uncial, the letters $\alpha$ ) and $\sigma$ with their 'Southern' shapes) and non-standard

(c) The Author(s), 2022. Published by Cambridge University Press. This is an Open Access article, distributed under the terms of the Creative Commons Attribution licence (http://creativecommons.org/licenses/by/4.0/), which permits unrestricted re-use, distribution and reproduction, provided the original article is properly cited. 
orthography ${ }^{1}$ point to a rather late (eighth- or even ninth-century?) date. Leo Depuydt's transcription of the fragment is often unreliable. ${ }^{2}$ A comparison of verses 1 Cor 15.3-4, 9-12 in P.MorganLib. 265 and 268 reveals that the two manuscripts bear witnesses to the same version; the differences are few and rather minor - viz. exeN-

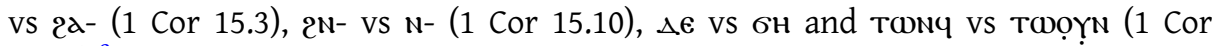
15.12). ${ }^{3}$

- P.Vindob. K 3280 + K 3921 + K 9311. Three fragmentary parchment leaves from a palimpsest, whose scriptio superior comprises 1 Cor 15.29, 32, 43-4, 45-7, 57-8; 16.1-2. According to Paul E. Kahle, the manuscript was copied in the seventh century or earlier. ${ }^{4}$ The fragments were edited by Walter C. Till, ${ }^{5}$ who could not identify the contents of the smallest of the three fragments - viz. P.Vindob. K 3280. Later, Kahle observed that the flesh side of the fragment contains 1 Cor 15.29, and the hair side 1 Cor 15.32. ${ }^{6}$ That this manuscript and P.MorganLib. 265 bear witness to the same version is clear from the fact that the poorly preserved text of 1 Cor 15.29 in P.Vindob. K 3280 can be easily restored with the help of P.MorganLib. 265. Unfortunately, since the fragment has been missing since $1971,{ }^{7}$ the following reconstruction is based solely on Till's transcription and needs to be revisited, should

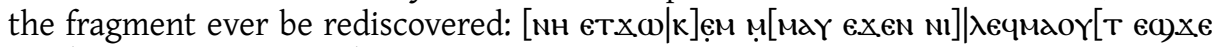

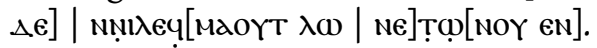

The only extant fragment in dialect F4 has parallel text with P.MorganLib. 268:

- Oxford, Bodleian Library, Ms.Copt.g.97(P). A fragment from a parchment codex whose text was arranged into two columns. It is paginated [P]N.A-PN[E] ('154-5') and preserves the top six lines on the right column of the recto and the left column of the verso. The existence of this fragment was signalled by Anne Boud'hors and Chièmi Nakano in $2005 .^{8}$ The recto, preserving 1 Cor 14.31 , reads: [rap] Mmaten |

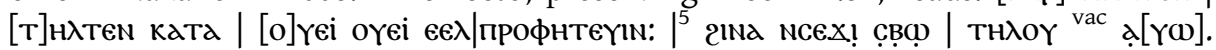

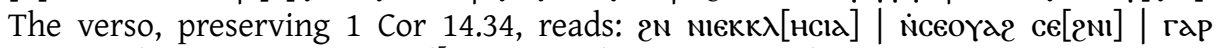

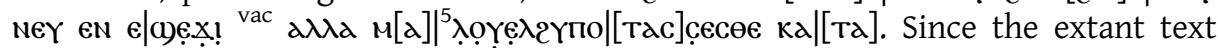
of 1 Cor 14.34 agrees verbatim with that in P.MorganLib. $268{ }^{9}$, we can be certain that Ms.Copt.g.97(P) bears witness to the same version as P.MorganLib. 265, 268 and P.Vindob. K $3280+\mathrm{K} 3921+\mathrm{K}$ 9311. To judge from the parallel text of bo and P.MorganLib. 268, Ms.Copt.g.97(P) must have had ca 22 lines per column. When it was complete, the leaf measured ca $155 \times 135 \mathrm{~mm}$ (height $\times$ width). Although we

\footnotetext{
${ }^{1}$ See I. Miroshnikov, 'A New Witness to the Fayyūmic Version of First Corinthians (P.MorganLib. 265). Part I: Notes on Codicology, Language, Provenance and Date', NTS 68 (2022) 89-104, at 100.

${ }^{2}$ L. Depuydt, Catalogue of Coptic Manuscripts in the Pierpont Morgan Library (2 vols.; Corpus of Illuminated Manuscripts 4-5; Leuven: Peeters, 1993) I.462. For instance, at 1 Cor 14.34, instead of 2Ynoedcceceє, read 2үпотассесеє; at 1 Cor 15.12, instead of $26 \mathrm{~N}_{2} \lambda \mathrm{l}$, read $2 \mathrm{~N}_{2} \mathrm{2l}[\mathrm{NI}]$.

${ }^{3}$ This list does not include the differences that are purely orthographic in nature (e.g. пюс vs пос) or that are due to scribal oversight (е.g. мпє†аl vs mпєalt).

${ }^{4}$ P. E. Kahle, Bala'izah: Coptic Texts from Deir el-Bala'izah in Upper Egypt (2 vols.; London: Oxford University Press, 1954) І.284.

${ }^{5}$ W. C. Till, 'Wiener Faijumica', Le Muséon 49 (1936) 169-217, at 199-201.

${ }^{6}$ See W. C. Till, 'Coptic Biblical Texts Published after Vaschalde's Lists', Bulletin of the John Rylands Library 42 (1959) 220-40, at 238.

${ }^{7}$ Claudia Kreuzsaler (Papyrus Collection, Austrian National Library), personal communication.

${ }^{8}$ A. Boud'hors and C. Nakano, 'Vestiges bibliques en copte fayoumique', JCoptS 7 (2005) 137-9, at 138-9.

${ }^{9}$ One possible exception is the omission of $\mathrm{d} \lambda \lambda \mathrm{d}$ in P.MorganLib. 268, as suggested by Depuydt, Catalogue, I.452

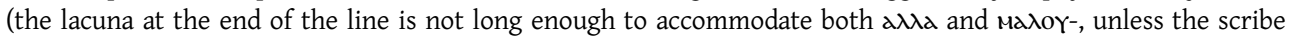
wrote maגoY- in the margin).
} 
should certainly be cautious when assigning dialects to small fragments such as this one, everything in Ms.Copt.g.97(P) - and especially the form $\mathrm{NE}=$ ('to, for'; F5 NH=) indicates that it belongs to the F4 corpus, which means that Ms.Copt.g.97(P) must have been produced sometime between the fourth and the sixth centuries CE.

There are also two manuscripts that do not preserve any text parallel with the other Fayyūmic witnesses to First Corinthians:

- P.Mich.inv. 158 (9) + P.MorganLib. 264. A fragmentary codex comprising the Pauline epistles, whose extant leaves are divided between the University of Michigan Library and the Morgan Library \& Museum. The Morgan fragments remain unpublished, while most of the Michigan fragments were edited by W. H. Worrell, ${ }^{10}$ who dated the manuscript to ca $600 \mathrm{cE}$; Kahle suggested a similar date. ${ }^{11}$ The codex may have belonged to the library of the White Monastery. ${ }^{12}$ Although this manuscript is by far our most important witness to the Pauline corpus in Fayyumic, only one leaf (P.MorganLib. 264, fol. 14) of First Corinthians survives, preserving most of its first chapter (1 Cor 1.1-7, 9-14, 16-24).

- P.Lond.Copt. 1.507. A strip of parchment, which once was part of a codex leaf, comprising 1 Cor $8.7,12-13$; 9.6-7, 12. After the strip was cut off, a liturgical aide-mémoire in Sahidic (P.Lond.Copt. 1.512) was inscribed above the older text. ${ }^{13}$ P.Lond.Copt. 1.507 was edited by W. E. Crum. ${ }^{14}$ Kahle dated it to the seventh century or earlier. ${ }^{15}$

Since no text has survived which would parallel that of these two manuscripts and the other four (i.e. P.MorganLib. 265, 268, Oxford, Ms.Copt.g.97(P) and P.Vindob. K $3280+\mathrm{K}$ $3921+K$ 9311), we cannot ascertain whether they bear witness to the same version of First Corinthians. However, although it is not impossible that the five extant Fayyumic manuscripts bear witness to two (or even three) different versions of First Corinthians, it seems reasonable to surmise that they all in fact represent one single version ( $\mathrm{fa}$ ) not only on the principle of lex parsimoniae, but also because, in all five, the text is strikingly similar to that of bo.

Indeed, a synoptic comparison of the vestiges of First Corinthians in Fayyumic with the Bohairic text immediately reveals that, if we disregard the dialectal differences, the two versions are next to identical. This similarity between fa and bo is remarkable and requires explanation. In the history of scholarship, two major Coptologists have expressed directly opposing views on the matter. According to Kahle, bo and fa are similar in several New Testament books, because, in these instances, fa 'was taken over' from and 'preserves almost literally the text of bo. In order to support his claim that fa is dependent on bo, Kahle refers to the fact that the standard Fayyümic nomina sacra $\bar{\varnothing}$ and $\overline{\overline{\sigma c}}$ derive from

\footnotetext{
${ }^{10}$ In a personal communication, Alin Suciu informed me that there are four small fragments of this manuscript in the Michigan collection that are not included in Worrell's publication. These fragments bear witness to the Fayyūmic text of Romans, Philippians, Second Thessalonians and Second Timothy.

${ }^{11}$ W. H. Worrell, 'Fayumic Fragments of the Epistles', BSAC 6 (1940) 127-39, at 127 (with reference to V. Stegemann, Koptische Paläographie (Quellen und Studien zur Geschichte und Kultur des Altertums und Mittelalters. Reihe C: Hilfsbücher 1; Heidelberg: Selbstverlag von F. Bilabel, 1936) Plate 8); Kahle, Bala’izah, I.284.

${ }^{12}$ Worrell ('Fayumic Fragments', 127) reports that P.Mich.inv. 158 (9) was purchased in Cairo 'along with leaves which were identified as of the White Monastery'.

${ }^{13}$ In a personal communication, Ágnes T. Mihálykó suggested that the hand of P.Lond.Copt. 1.512 should be dated to the eleventh century $\mathrm{CE}$.

${ }^{14}$ W. E. Crum, Catalogue of the Coptic Manuscripts in the British Museum (London: British Museum, 1905) 243.

${ }^{15}$ Kahle, Bala'izah, I.284.
} 
Bohairic. ${ }^{16}$ This argument was refuted by H. J. Polotsky, who noted that the borrowing of nomina sacra from a neighbouring dialect does not provide sufficient grounds to posit literary dependence. ${ }^{17}$ The question about the relationship between fa and bo thus remains open, though Polotsky himself felt that 'it is not only possible, but plausible' that the former has priority over the latter. ${ }^{18}$

With respect to First Corinthians, a comparison of fa and bo makes either of these two simple solutions ( $\mathrm{fa} \rightarrow$ bo vs bo $\rightarrow \mathrm{fa}$ ) rather unlikely. That neither of them can be a daughter version of the other is best evidenced by those instances where bo and fa support different variant readings of the Greek tradition. For instance, at 1 Cor 3.5, bo reads

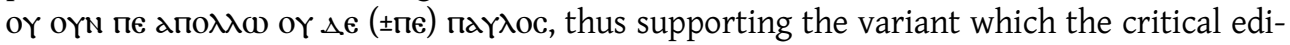

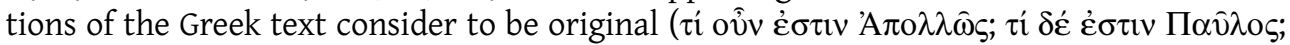
'What, then, is Apollos, and what is Paul?'). Fa, on the other hand, reverses the order of

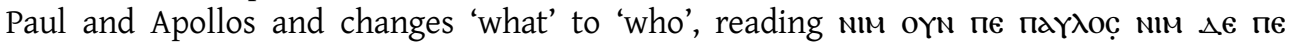

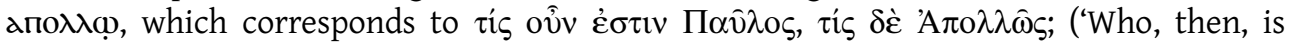
Paul, and who is Apollos?'). This latter reading, which is clearly secondary, ${ }^{19}$ is attested in several Greek witnesses, most notably in the Byzantine text.

That fa cannot be a daughter version of bo is also indicated by the numerous instances where a Greek word is translated in bo but retained in fa - e.g. epa)ı)ı vs ezorcla (1 Cor

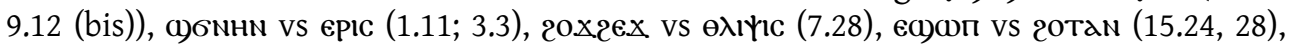

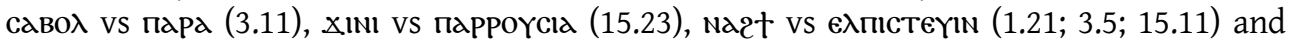
mictıc $(15.14,17)$, etc. Although we could hypothesise that the Fayyūmic translator merely 'guessed' the Greek lexeme behind the Bohairic word (which would not be difficult with e.g. $\pi \imath \sigma \tau \varepsilon v i \varepsilon v$ or $\pi i \sigma \tau \iota \varsigma)$, in some instances this is rather unlikely. Perhaps the most strik-

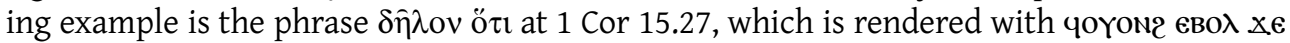
in bo, while the parallel text of fa reads $\Delta H \lambda$ ON $\omega \mathrm{TI}$. Conversely, there are also numerous instances where a Greek word is translated in fa but retained in bo, which indicates that bo cannot be a daughter version of fa - e.g. mNCoc vs ita (1 Cor 15.7), אec vs alnd (7.29),

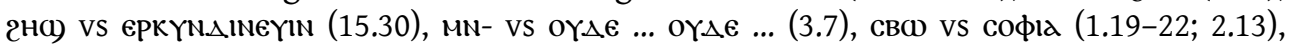
гдт2єт vs ерсүNKPININ (2.13).

In sum, neither is fa a direct transposition of bo, nor bo a direct transposition of fa; we thus need to inquire into the more complicated scenarios that would account for the remarkable similarity of the two versions. One way to explain the data reviewed above would be to identify bo with the original translation, of which fa would be a revision

\footnotetext{
${ }^{16}$ Kahle, Bala'izah, I.228-9, 248, 280.

${ }^{17}$ According to Polotsky, a similar phenomenon also occurs in the Mesokemic $(M)$ dialect, which uses the nomen sacrum $\overline{\Pi N}$, even though the non-abbreviated form of the word 'god' in $M$ is Norte. Since the Fayyūmic form of the word is Nort, the abbreviation $\overline{\Pi N} \mp$ in $M$ must be a borrowing from Fayyūmic (so also H.-M. Schenke, Das Matthäus-Evangelium im mittelägyptischen Dialekt des Koptischen (Codex Scheide) (Texte und Untersuchungen zur Geschichte der altchristlichen Literatur 127; Berlin: Akademie, 1981) 32; idem, 'Notes on the Edition of the Scheide Codex', Acts of the Second International Congress of Coptic Studies (ed. T. Orlandi and F. Wisse, Rome: CIM, 1985) 315-16; idem, 'On the Middle Egyptian Dialect of the Coptic Language', Der Same Seths: Hans-Martin Schenkes Kleine Schriften zu Gnosis, Koptologie und Neuem Testament (ed. G. S. Robinson, G. Schenke and U.-K. Plisch; Nag Hammadi and Manichaean Studies 78; Leiden: Brill, 2012) 424-46, at 439-40). This inference, however, is difficult to reconcile with the fact that $\overline{\mathrm{nN}} \overline{\mathrm{n}}$ never occurs in Fayyumic manuscripts. It is, perhaps, more plausible that both Fayyūmic and Mesokemic are, in this regard, dependent on Bohairic, but, while Fayyūmic retains the Bohairic form, Mesokemic makes it more similar to the local idiom (which does not have consonant aspiration). This suggestion receives some support from the fact that the Bohairic $\Phi \mp$ and the Bohairic-like $\overline{\Pi \mp}$ occur in the $M$ corpus alongside $\overline{\Pi N} \mp$, even though the latter is certainly more common.

${ }^{18}$ H. J. Polotsky, Collected Papers (Jerusalem: Magnes, 1971) 234.

${ }^{19}$ See B. M. Metzger, A Textual Commentary on the Greek New Testament (Stuttgart: Deutsche Bibelgesellschaft, $\left.1994^{2}\right) 483$.
} 
made in consultation with the Greek text. However, this explanation seems to contradict what we know about the history of fa and bo. As evidenced by Oxford, Ms.Copt.g.97(P), the text of First Corinthians was available already in the early variety of Fayyūmic - viz. dialect F4. Moreover, a comparison of the text of 1 Cor 14.34 in the Oxford fragment with that in P.MorganLib. 268 confirms that the Fayyūmic textual tradition was stable - that is, despite the transition from $F 4$ to $F 5$, 'the same text form was maintained during the editing process'. ${ }^{20}$ We thus have good reason to suppose that a Fayyūmic translation of First Corinthians was produced rather early (perhaps even as early as the fourth century) and that it was similar to the version available to us today. On the other hand, we also have good reason to believe that the Bohairic Bible was produced in the seventh or eighth century $\mathrm{CE}$, superseding the Paleo-Bohairic version (pbo), which was written in a different variety of Bohairic (dialect B4). ${ }^{21}$ In sum, the claim that fa is a revision of bo is problematic, because, in all likelihood, fa predates bo by several centuries.

Alternatively, we can hypothesise that bo is a revision of fa made in consultation with the Greek text. This hypothesis is, as far as I can see, within the realm of possibility. It is worth noting, however, that, as I demonstrated in an earlier publication, bo of Hebrews was the result of a thorough revision of pbo, the redactor's goal being to adjust the Coptic text to a word-for-word correspondence with the Greek. ${ }^{22}$ It is not impossible that not only Hebrews, but the entire Bohairic Pauline corpus went through this process, in which case bo of First Corinthians would be a revision of pbo. The text of this hypothetical precursor of bo would then be even closer to that of fa. One of the many differences between pbo and bo of Hebrews is their use of Greek discourse markers - while bo tends to faithfully retain the discourse markers of the Greek text, pbo exhibits a remarkable degree of variation. ${ }^{23}$ Although pbo of First Corinthians is lost, it is perhaps significant that a comparison of fa and bo reveals a similar phenomenon - bo tends to be literal, while fa often departs from the Greek (see p. 212 below). It is possible, therefore, that the literalness of bo is a secondary development, while the more liberal attitude towards discourse markers in fa was also characteristic of pbo.

Unfortunately, beyond this point, we find ourselves entirely within the realm of speculation. Since the text of pbo is no longer available, we cannot arrive at any secure conclusions about its relationship to fa. Perhaps pbo (of which bo was a revision) was a daughter version of fa; perhaps fa is a daughter version of pbo. Moreover, the very notion that the dialect of the original translation was either Bohairic or Fayyūmic may be misleading. It is possible that both versions were 'original', in the sense that neither of them was a transposition of the other. Since the regions in which Bohairic and Fayyümic were the dominant dialects were adjacent to one another, we can imagine two groups of translators working in consultation with each other, one responsible for pbo and the other for fa. While all these scenarios are hypothetical (and must remain hypothetical until the discovery of new evidence), they must be closer to the truth than the solutions championed by Kahle (bo $\rightarrow \mathrm{fa}$ ) and Polotsky (fa $\rightarrow$ bo).

Having discussed the relationship between fa and bo, I should also say a few words about codex C. According to Kahle, this manuscript 'is based on the text of the Sahidic Version, but a number of variants point to influence from the Fayyumic-Bohairic text.. ${ }^{24} \mathrm{~A}$

\footnotetext{
${ }^{20}$ W.-P. Funk, 'The Translation of the Bible into Coptic', The New Cambridge History of the Bible, vol. I (ed. J. C. Paget and J. Schaper; Cambridge: Cambridge University Press, 2013) 536-46, at 542.

${ }^{21}$ C. Askeland, John's Gospel: The Coptic Translations of its Greek Text (Arbeiten zur neutestamentlichen Textforschung 44; Berlin: de Gruyter, 2012) 177.

${ }^{22}$ I. Miroshnikov, 'A New Witness to the Paleo-Bohairic Version of the Bible: A Fragmentary Manuscript of the Epistle to the Hebrews in Early Bohairic', JCoptS 21 (2019) 173-208, at 189-90.

${ }^{23}$ Miroshnikov, 'Hebrews in Early Bohairic', 185-6.

${ }^{24}$ Kahle, Bala’izah, i.285.
} 
comparison of the text of First Corinthians in fa, bo and codex $\mathrm{C}$ confirms this claim. For

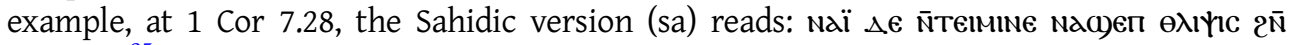
Tercapz. ${ }^{25}$ In this instance, codex $\mathrm{C}$ departs from sa and follows fa and bo, as the following comparison demonstrates:

\begin{tabular}{|c|c|c|c|c|c|c|}
\hline Codex C & $\epsilon \gamma \epsilon\left[\begin{array}{ll}x_{1} & \Delta\end{array}\right] \epsilon$ & 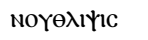 & NTEYCaPez & NG1 & Nel & NTEI2H \\
\hline $\mathrm{fa}$ & $\epsilon \gamma \epsilon x_{1} \Delta \epsilon$ & 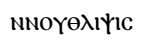 & етеүсарz & NXe & Nel & NTEI2H \\
\hline bo & $\epsilon \gamma \epsilon \sigma 1 \Delta \epsilon$ & Nor2oxiex & NTOYCAPz & NXE & $\mathrm{Nal}$ & мпаІрн† \\
\hline
\end{tabular}

Codex C, fa and bo agree against sa in using subject inversion, third future and the verb 'to take' in the absolute state with the indefinite object; that codex C here draws on either fa or bo is thus beyond doubt. Since the translator and/or copyist(s) of the text preserved in codex $C$ attempted to approximate some sort of Fayyūmic and since this manuscript, while littered with Sahidicisms, does not seem to have been influenced by Bohairic, we can tentatively assume that it was fa, not bo, that was the source of influence.

\section{Variant Readings}

Finally, I proceed to a discussion of the importance of P.MorganLib. 265 for the textual criticism of the Greek New Testament. There are several instances where fa, represented by P.MorganLib. 265, supports one of the variant readings attested in the Greek tradition; of those, some variants probably belong to the original text of Paul's letter - e.g. the

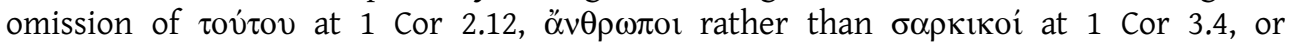
$\delta \omega \delta \varepsilon \kappa \alpha$ rather than $\varepsilon \check{v} \delta \varepsilon \kappa \alpha$ at 1 Cor 15.5. Other variants, according to Nestle-Aland,

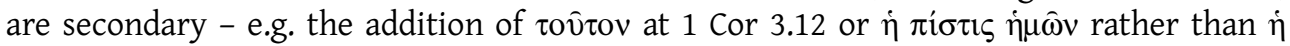
$\pi i \sigma \tau ı \zeta$ v $\mu \hat{\omega} v$ at 1 Cor 15.14 .

It is also worth noting that, compared to fa, one particular Greek manuscript seems to

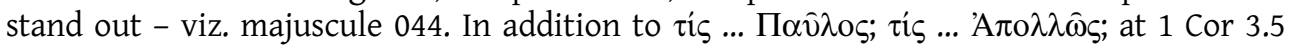
(which is typical for manuscripts representing the Byzantine text), it also agrees with fa in

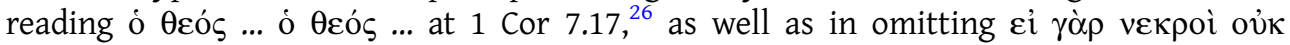

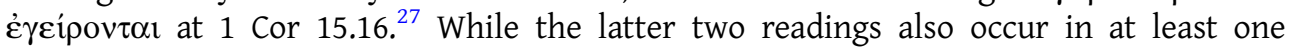
other Greek witness - viz. minuscule 1563 - majuscule 044 seems to be the only Greek manuscript that agrees with fa in omitting $\pi \alpha \dot{v} \tau \alpha \varsigma$ at 1 Cor 15.25. Admittedly, when taken in isolation, the agreement between majuscule 044 and fa in each of the latter three cases could be explained as mere coincidence. For instance, it seems reasonable to surmise that the omission of 'all' at 1 Cor 15.25 is due to harmonisation to Ps 109/ 110.1. It is not impossible that this omission was absent from the Greek Vorlage of fa

\footnotetext{
${ }^{25}$ H. Thompson, ed., The Coptic Version of the Acts of the Apostles and the Pauline Epistles in the Sahidic Dialect (Cambridge: Cambridge University Press, 1932) 129.

${ }^{26}$ This reading is attested in at least four other Greek manuscripts - viz. 629, 1563, $1573^{c}$ and 2400.

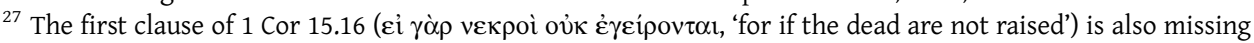
from at least five other Greek manuscripts - viz. 131, 1563, 1646, 1900 and 1962. Admittedly, there is one Greek manuscript (Codex Claromontanus) that, instead of the first clause of 1 Cor 15.16, omits the final clause of 1 Cor

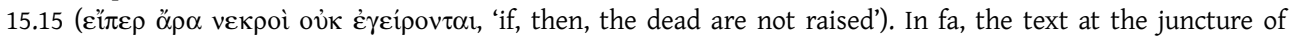

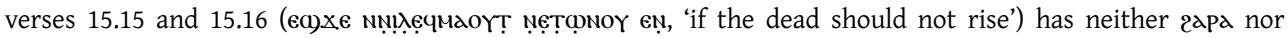
rap, and thus it is difficult to ascertain which of the two clauses was omitted. It seems more plausible, however, that fa supports the reading of majuscule 044 rather than that of Codex Claromontanus, given that the omission of the first clause of 1 Cor 15.16 is better attested in the Greek manuscript tradition and is easier to explain (viz. due to homoeoteleuton). Moreover, this omission, unlike the omission of the final clause of 1 Cor 15.15, also occurs in the Coptic witnesses (at least two witnesses of bo and at least one witness of sa - viz. codex C).
} 
and came about either during or after the translation event. ${ }^{28}$ Cumulatively, however, the agreements between majuscule 044 and fa suggest that, in all these verses, the Vorlage of fa had the same variants as majuscule 044 .

Some of the variants do not seem to be attested in the Greek manuscript tradition, and we thus cannot know whether they reflect the Greek Vorlage of fa or whether they should be regarded as an alteration that occurred during or after the translation event. Thus, in the text of Ps 8.7 (quoted at 1 Cor 15.27), fa - unlike all known Greek witnesses - has the nominal subject (viz. 'God'); although it is clear that this alteration, intended to make the biblical text more straightforward, is secondary, we cannot know at what point in the transmission history of the text it was introduced. A similar case occurs at 1 Cor 3.1, where fa reads 'Christ Jesus', while the Greek has only 'Christ'.

Interestingly, some of the readings in fa that are absent in the Greek tradition also occur in other early translations. At 1 Cor 7.24, where the Greek text reads $\dot{\varepsilon} v \hat{\hat{\omega}} \dot{\varepsilon} \kappa \lambda \dot{\eta} \theta \eta$ ('wherein he was called'), the phrasing of fa is identical to that of Cor 7.20 (2м птогем Nтаүтагмеч

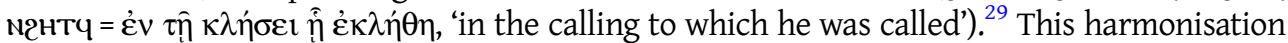
also features in two manuscripts of Ambrosiaster (in qua vocatione vocatus est). ${ }^{30}$ Similarly,

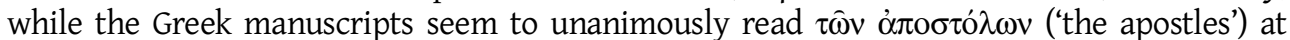

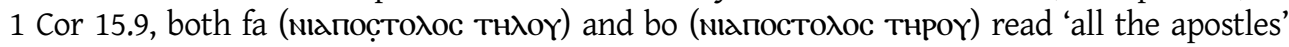
(a harmonisation to 1 Cor 15.7), which finds parallel in the Old Latin tradition (omnium apostolorum). ${ }^{31}$ Although these harmonisations may have happened independently, the possibility that they existed in Greek cannot be completely ruled out.

With regard to the use of Greek discourse markers, the evidence of fa should be used with extreme caution. There are numerous instances in which fa adds a discourse marker where the critical edition of the Greek text has none. ${ }^{32}$ There are also instances in which fa omits the discourse marker we have in the Greek, ${ }^{33}$ or even replaces it with a different one. ${ }^{34}$ Most of these variants also occur in at least some of the witnesses of bo. On the other hand, in all these instances, the support of the Greek manuscript tradition is either insignificant or completely absent. It seems reasonable then to surmise that most, if not all, of these variants occurred at the Coptic stage of the transmission of the text of First Corinthians and thus have no relevance to the study of the Greek Vorlage of fa.

Some of the unique readings in fa are due to scribal errors. For instance, at 1 Cor 7.19, fa reads 'circumcision is nothing, but uncircumcision is nothing', with $2 \lambda \lambda d$ ('but') where

\footnotetext{
${ }^{28}$ It is worth noting, however, that Ps $109 / 110.1$ (fa), whose text survives on P.Vindob. K 50 - a small $(2 \times 11$

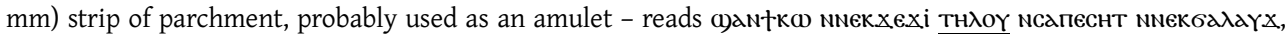
'until I have put all your enemies under your feet'. The text of Ps 109/110.1 (fa) is thus assimilated to that of 1 Cor 15.25 - the exact opposite of what we observe at 1 Cor 15.25 (fa). Since Ps 109/110.1 (fa) has 'all', it follows that the harmonising reading we find at 1 Cor 15.25 ( fa) must have come about before the translation event - we would otherwise have to assume that the text of Ps 109/110.1 known to the Fayyūmic translator of 1 Corinthians was different from that of P.Vindob. K 50 (e.g. he could have been drawing on the quotation from Ps 109/110.1 in Matt 22.44, Mark 12.36, Luke 20.43 or Acts 2.35 , none of which passages, to my knowledge, survive in Fayyūmic). For an edition of P.Vindob. K 50, see V. Stegemann, Die koptischen Zaubertexte der Sammlung Papyrus Erzherzog Rainer in Wien (Sitzungsberichte der Heidelberger Akademie der Wissenschaften, Philosophisch-historische Klasse, Jahrgang 1933/4, 1. Abhandlung; Heidelberg: Winter, 1934) 25-6, 62-3; W. Till, 'Zu den Wiener koptischen Zaubertexten', Orientalia 4 (1935) 195-221, at 214.

${ }^{29}$ This reading also occurs in a number of witnesses to bo (bєN пөсгєм єтаүөдгмєч м̈нтт).

${ }^{30}$ H. A. G. Houghton, C. M. Kreinecker, R. F. MacLachlan and C. J. Smith, The Principal Pauline Epistles: A Collation of Old Latin Witnesses (New Testament Tools, Studies and Documents 59; Leiden: Brill, 2019) 216.

${ }^{31}$ Houghton, Kreinecker, MacLachlan and Smith, Principal Pauline Epistles, 281.

${ }^{32}$ At 1 Cor $15.26,29$, $\delta \dot{\varepsilon}$ is added and should probably be reconstructed at 1 Cor $7.24 ; \gamma \alpha \dot{\rho} \rho$ is added at 1 Cor 7.19; oûv, at 1 Cor $3.17,18$.

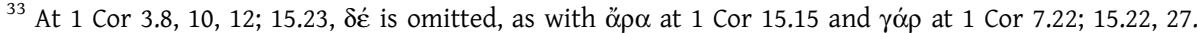

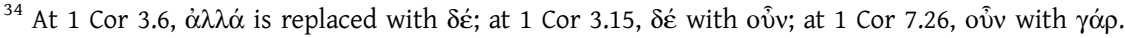




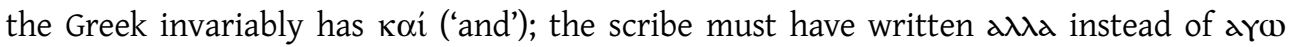
('and') by mistake, in anticipation of $a \lambda \lambda d$ in the following clause. Similarly, $\pi \in \Pi \bar{N} \alpha$ ('the Spirit') instead of пепі̄ instead of maגion ('rather') at 1 Cor 7.21 are due to scribal oversight.

Finally, the last clause of 1 Cor 15.27 (fa) deserves special commentary. Here, bo reads батеN фн етачөре enXal niBen one XwoY nay ('except the one who made everything be

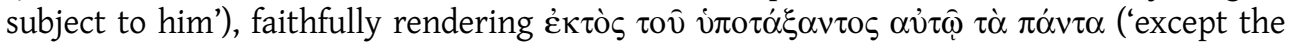
one who subjected all things to him'). The text of fa, on the other hand, corresponds to

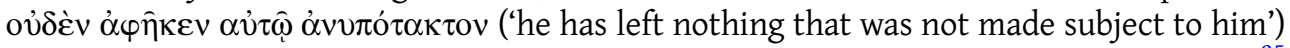
of Heb 2.8, thus bearing witness to a reading that has no support in the Greek tradition. ${ }^{35}$ This assimilation of 1 Cor 15.27 to Heb 2.8 was undoubtedly triggered by the fact that both passages offer an exegesis of the same Old Testament passage (viz. Ps 8.7) and that both were considered to be written by the same author (viz. Paul). As the following comparison demonstrates, the text of 1 Cor 15.27 (fa) is identical to that of Heb 2.8 (bo). ${ }^{36}$

\section{Cor 15.27 (fa)}

Heb 2.8 (bo)

\section{мпєчке}

$\lambda а п \mathrm{C}$

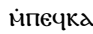

NNOYea)

พंoYec)en єлгнпотацєсеє

GNE XWOY
NHY

NaY

The verbatim agreement between 1 Cor 15.27 (fa) and Heb 2.8 (bo) indicates that, at this point, fa presupposes the existence of a Coptic translation of Hebrews (which was either identical with or similar to bo). ${ }^{37}$ It seems reasonable to surmise, then, that the wording of 1 Cor 15.27 (bo) reflects that of the original translation, while the harmonising reading that we now find at 1 Cor 15.27 (fa) was introduced by a later redactor or copyist.

In what follows, I offer a semi-diplomatic edition of P.MorganLib. 265, which I autoptically examined at the Morgan Library \& Museum in May 2019. Due to the current state of preservation of the manuscript, some portions of the text are illegible under natural light. More text is legible on the photographs reproduced in Henri Hyvernat's facsimile, ${ }^{38}$ but, unfortunately, these photographs were taken before the fragments were detached from each other and cleaned. The staff at the Morgan Library \& Museum kindly let me examine P.MorganLib. 265 under ultraviolet light, which allowed me to significantly improve the transcription. Afterwards, I checked and corrected this initial transcription with the help of the ultraviolet images produced at the library's photographic studio.

\footnotetext{
${ }^{35}$ To the best of my knowledge, the closest parallel to 1 Cor 15.27 (fa) occurs in two Old Latin manuscripts $\left(54^{c}\right.$ and 58), which add either nihil praetermisit non subjectum ei ('he has overlooked nothing that had not been made subject to him') or nihil domini sit non subjectum ei ('the Lord has nothing that has not been made subject to him') before praeter eum qui subjecit ei omnia ('except the one who subjected all things to him'). The Latin text is from Houghton, Kreinecker, MacLachlan and Smith, Principal Pauline Epistles, 285. The difference in wording may indicate that the reading attested in these two manuscripts also existed in Greek. It is worth noting, however, that nihil domini sit in manuscript 58 is undoubtedly a corruption of nihil dimisit ('he has left nothing'; the verb dimisit was mistaken for the DMI followed by sit), which is what the Vulgate reads at Heb 2.8. Given that the two readings differ only in the prefix (di- vs praeter-, the latter probably triggered by the following praeter eum), I am sceptical that a similar reading ever existed in Greek. Since fa and the two Old Latin witnesses differ in that the former replaces a clause from 1 Cor 15.27 with a clause from Heb 2.8, while the latter conflate the two phrases, I would argue that the two harmonisations happened independently.

${ }^{36}$ The only differences are lexical, conditioned by the different vocabularies of F5 and B5 - e.g. fa opts for the

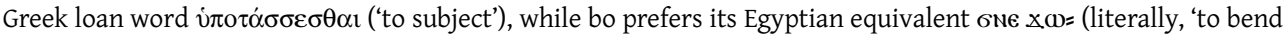
one's head').

${ }^{37}$ Unfortunately, we cannot know whether bo and fa of Heb 2.8 were identical, since the latter has not survived.

38 [H. Hyvernat], Bybliothecae Pierpont Morgan codices coptici photographice expressi (56 vols.; Rome: [s.n.], 1922) xxxvIII.3-4, 103-5.
} 
In my edition, I have followed the principles of word division outlined by Walter C. Till. ${ }^{39}$ In addition to the use of the underdot to indicate where the extant ink traces are paleographically ambiguous, I also use it in those instances where the parchment is intact but the Coptic text seems to have entirely vanished. Coptic letters that are missing due to the loss of written surface are enclosed in square brackets.

The edition is followed by my notes on the Coptic text and an English translation. In the translation, Greek loanwords employed in the Coptic text are given as parenthetical glosses. In my translation, I have tried to retain the diction of the original Coptic as literally as possible, which unavoidably impairs the eloquence of the English. In the footnotes to the translation, I explicate the meaning of those passages that might otherwise be unclear in translation to the reader.

\footnotetext{
${ }^{39}$ W. C. Till, 'La séparation des mots en copte', BIFAO 60 (1960) 151-70.
} 


\section{Transcription of the Coptic Text}

Fol. $(c+a)^{r}\left(\right.$ MS M.585, fol. $50^{\mathrm{v}}+$ fol. $i^{\mathrm{r}}$; see Fig. 1)

2.12

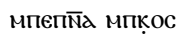

MOc EN חeTạạ

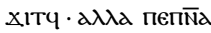

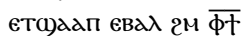

[ח]

!MI ENH NTd $\overline{\phi \dagger}$ Tel

TOY NHN N2MAT

2.13 ETE NEI NE NETE

()) $\mathrm{X} I \mathrm{MMAY}$

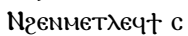

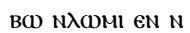

TE $2 \in N() \in X I N C$

$B O \cdot \cdot 2 \lambda \lambda d 2 \mathrm{~N} 2 \mathrm{EN}$

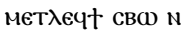

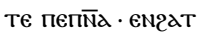

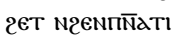

KON $\cdot$ MN $2 \in N \Pi \bar{N} d$

2.14 тікос $\cdot$ пוҮҮн

KOC $\Delta \in \mathrm{N} \lambda \omega \mathrm{MI}$ MєY

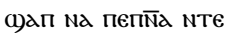

$\overline{\phi \dagger}$ eגaq. оүмет

caG гар NHY TE

Аүळ MMN C)GамMач

еІмі $x \in$ аүгатгет

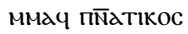

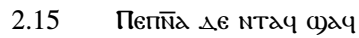
2аT2еT NKEеNI NI $\mathrm{Bl} \cdot \mathrm{NTAY} \Delta \epsilon \mathrm{Me \lambda \epsilon}$

入апс гетготч

2.16 Nim гар петадчім

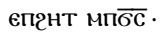

Emman Nim пет NeC)TCaBdy

dNAN $\triangle \epsilon$ пथнT M

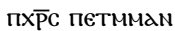

3.1 dNaK $\Delta \in 20 \mathrm{NaC}$ NHOY MாІ) $6 \mathrm{M}$ бамм е()еХI Nемн TEN NT2H N2EN

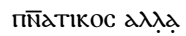

NT2H N2ENCAP

КІкос ṆT2H N2ё

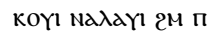

$5 \quad \times \overline{\mathrm{P}} \mathrm{i} \mathrm{\textrm {H }} \mathrm{C}$.

Oүapot altca TH

NOY MMAC NNOY?

PH EN TE - ENEM

патетеNO) $6 \in M$

10 бам гар пе. $2 \lambda \lambda \alpha$

†NOY AN MMN C)

aMMATEN

ETI rap nTeten qе

capkikoc

15 2ос гар Eоүan кw? 2l epic 2n ThNoY

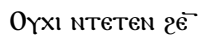
capкIкоc.

20

dYW ateTenmá

ad)ı KaTd $\lambda \omega M !$

Єо)шा гар алє

a)doүe! Xac $x \in$

aNAK MEN ANAK

па паүлос.

KeoYel $\Delta \in$ Xe anak

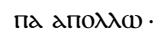

OYXI nTETEN 2EN 入оми.

Nim оYN пе паY入oc

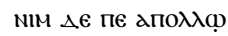

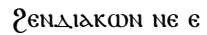
атетеNEAпICTEY!̣

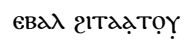

Поүе1 поүеі ката

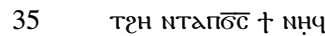

dNAK AITWGI

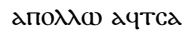
$\overline{\phi \dagger} \Delta \epsilon$ ачтроүale! гос $\triangle \epsilon$ петтоб! 


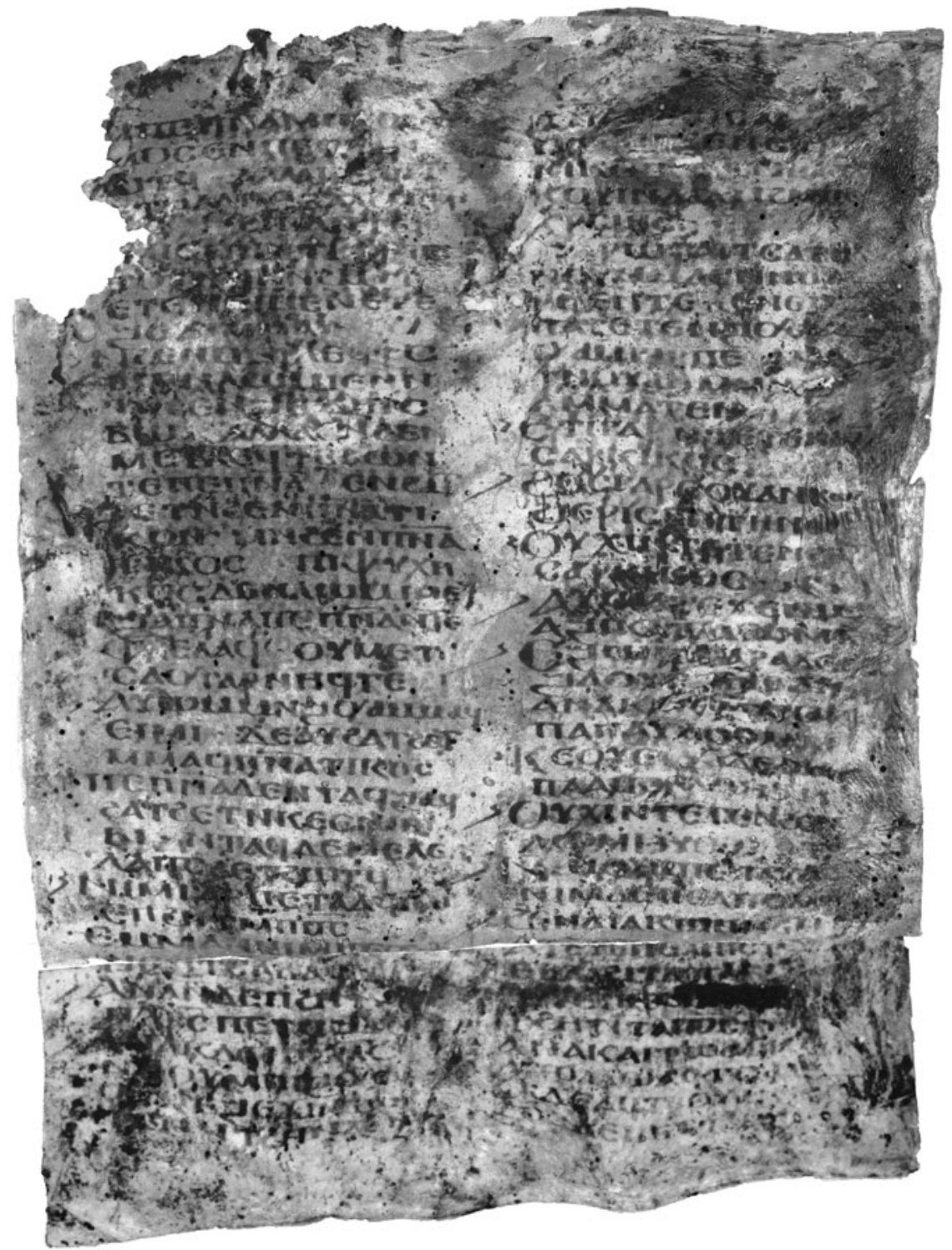

Figure I. The Morgan Library \& Museum, MS M.585, fol. $50^{\vee}+$ fol. ir. Purchased for J. Pierpont Morgan (18371914) in 1911. Digitally reassembled by Ivan Miroshnikov. 
Fol. $(c+a)^{v}\left(\right.$ MS M.585, fol. $50^{\mathrm{r}}+$ fol. $i^{\mathrm{v}}$; see Fig. 2)

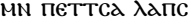

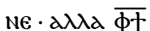

петтроүale

3.8

Петтобı мN пєт

TCd orel ne

Поүе $\Delta €$ поүеі

чNEXI мпечве

КН Ката печश

Cl MMIN MMAY

3.9

dNAN rap aNed $\alpha$

BH入 $N \lambda \epsilon 4 \epsilon \lambda$ 20B

NTE $\overline{\phi \dagger} \cdot$ MN OYle

noYadle nTe $\overline{\phi \dagger}$

NTETEN OYKळT

$3.10 \quad$ NTE $\overline{\phi \dagger} \cdot$ KaTd пє2

MaT NTE $\overline{\phi \dagger} \in \mathrm{T}$

TdAI NHI .

Nт2н NOYCaBH

NAPXI $\triangle$ EKTON

dika NOYCent

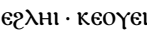

петоүегем кळт

Поүек $\triangle \epsilon$ поүє

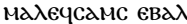

Xe дчк(1) Ne()

3.11

$\mathrm{N} 2 \mathrm{H} \cdot \mathrm{KeCEN}+$

TaP MN C)GAM N

текеоүеІ кес е2

$\lambda \mathrm{Hl} \cdot$ пард TET

KH $е 2 \lambda H \mathrm{H}$ eTE $\mathrm{l} \overline{\mathrm{HC}}$

$3.12 \pi \times \overline{\mathrm{P}} \mathrm{c} \pi \epsilon \cdot \epsilon \alpha) \times \epsilon$

OYAN пеTOY

егем кळT EXeN

TeICENT NOY

NOYB MN OY2еT

дNAMMEє1.

а)н саүвоҮ $\lambda$ аү! пгов мпоүеІ

поҮе1 чNeоYळ[N2]

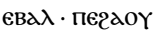

гap чneoran? [q]

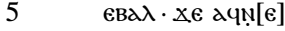

$\sigma \omega \lambda \Pi \operatorname{eBd\lambda } 2 \mathrm{~N}$

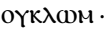

Аүш пгов мпоү el поүе1.

10

пек入Фм петне

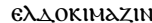

MMAY - XE oүed)

N2H пе .

Пн ете печгов ме

GONT NTAY

KATY Y YNEXI M

печвекн .

Пн етепечгов

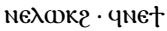

20 асl ммач NTач

$\triangle \in$ पNENOYZM

$N T\{a \varphi\}<\epsilon 1>2 H$ OYN $е B d \lambda$

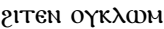

NTETEnCdOYN

25

EN-XE NTETEN

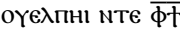

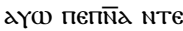

$\overline{\phi \dagger} \cdot \varphi() d a \Pi$ 2N TH

NOY · ПH OYN ET

30

Necdaप пе入пHI

$\mathrm{M \overline { \phi }} \cdot \pi \epsilon \overline{\phi \dagger} \mathrm{N \epsilon}$

такау

гAP NTE $\overline{\phi \dagger}$ oүeB

ете NTATEN пе

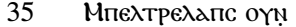

e $2 € \lambda$ mMay oYa

ЕТч. пєтмн

OY! হุN THNọ
3.13

3.14 


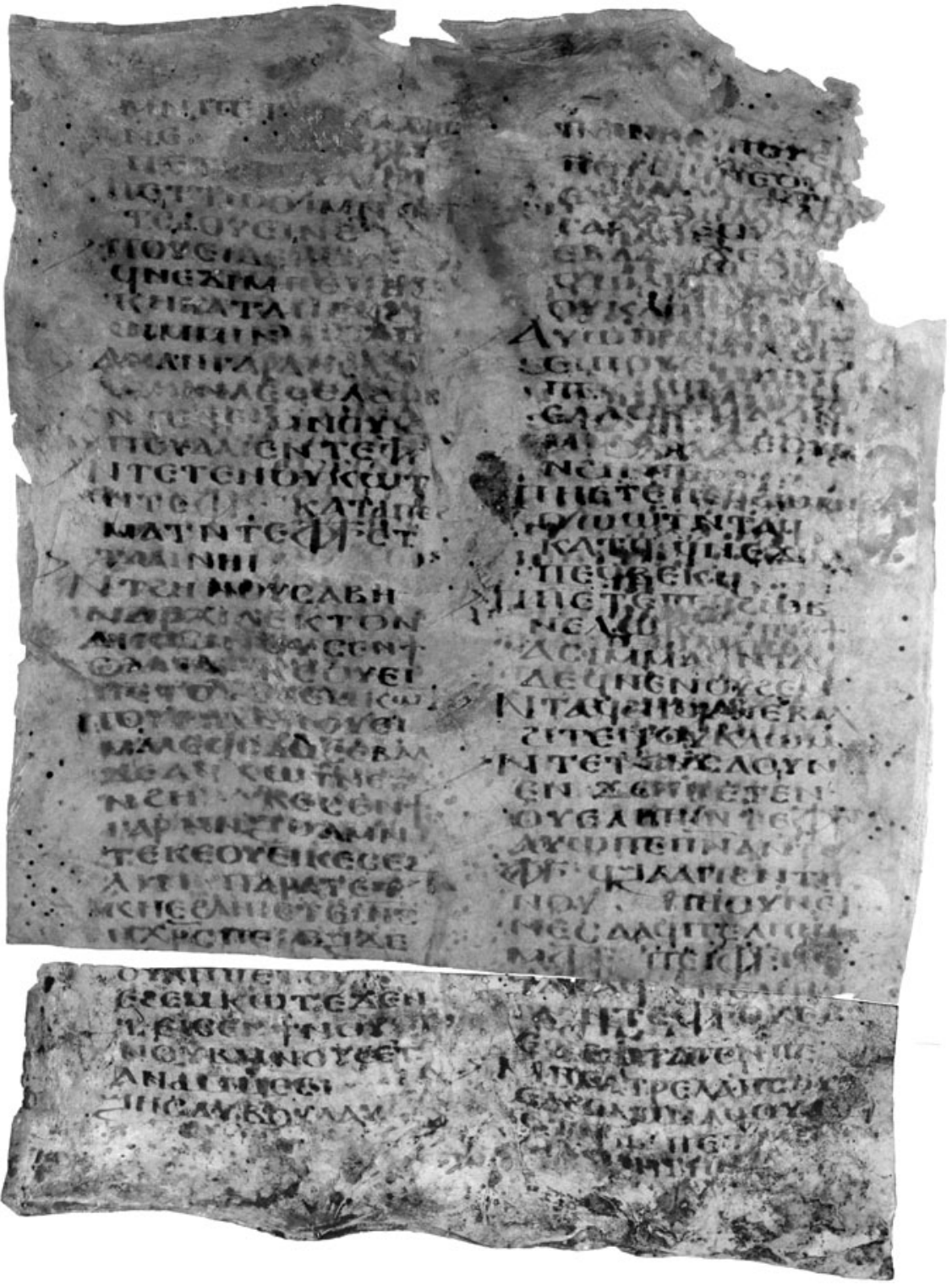

Figure 2. The Morgan Library \& Museum, MS M.585, fol. $50^{r}+$ fol. $i^{v}$. Purchased for J. Pierpont Morgan (I8371914) in 1911. Digitally reassembled by Ivan Miroshnikov. 
Fol. $(d+e)^{r}\left(\right.$ MS M.585, fol. $51^{\mathrm{v}}+$ fol. $51^{\mathrm{r}}$; see Fig. 3)

\begin{tabular}{|c|c|c|c|c|}
\hline [ & ] & & 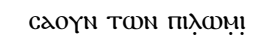 & 7.16 \\
\hline [ & ] & & $x \in$ кNє) & \\
\hline [ & ] & & сәІмІ ємес)ні NT & 7.17 \\
\hline [ & ] & & 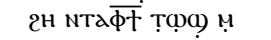 & \\
\hline [ & ] & 5 & поүев поүев & \\
\hline [ & ] & & 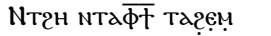 & \\
\hline [ & ] & & поүєі поүєı мтє! & \\
\hline [ & ] & & 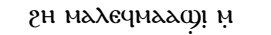 & \\
\hline [ & ] & & MaC. NTEIQH AN + & \\
\hline [ & ] & 10 & OYd2 Ce्2NI NNIEKK & \\
\hline [ & ] & & 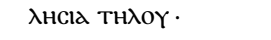 & \\
\hline [ & ] & & АҮтג2єм оүє1 єчснв & 7.18 \\
\hline [ & ] & & вноҮт мпє入треч & \\
\hline [ & ] & & сак тметдтснвві & \\
\hline [ & ] & 15 & NHY· aYTaгєм OY & \\
\hline [ & ] & & el 2N TMєTаTснвBI & \\
\hline [ & ] & & мпє入трєчснввнтч & \\
\hline [ & ] & & Пснввı гар Адпс пє & 7.19 \\
\hline [ & ] & & 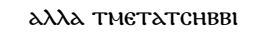 & \\
\hline [ & ]. & 20 & $\lambda \alpha \Pi C \mathrm{Te} \cdot 2 \lambda \lambda d$ па & \\
\hline [ & ]ழс & & $\lambda \epsilon 2$ пє м̣NIєNTO入HOY & \\
\hline [ & ] $x \in$ & & ̣. $\overline{\phi \dagger} \cdot$ поҮеı поҮ & 7.20 \\
\hline [ & lt & & el 2M пT02єM NTAY & \\
\hline [ & ].c & & ТА२меч N2HTY Mа & \\
\hline [ & ] & 25 & 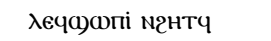 & \\
\hline [ & ]$\pi$ & & 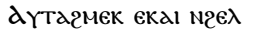 & 7.21 \\
\hline [ & ] & & мпє $\lambda T \in с \epsilon \lambda M € \lambda$ & \\
\hline [ & ] & & єсө€ NHK. & \\
\hline [ & ] & & $d \lambda \lambda d \in \alpha) x \in$ oYdan $\alpha) G$ & \\
\hline [ & ]or & 30 & dM MMaK $\epsilon € \lambda \lambda \in M 2 H$ & \\
\hline [ & ].dT & & MONON $\alpha \lambda ! ̣ \lambda l$ & \\
\hline [ & ] & & 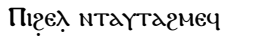 & 7.22 \\
\hline [ & ] & & 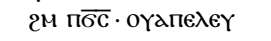 & \\
\hline [ & ] & & 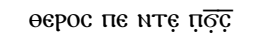 & \\
\hline [ & ] & 35 & 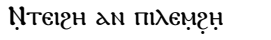 & \\
\hline [ & ] & & 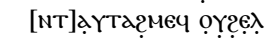 & \\
\hline [ & ] & & 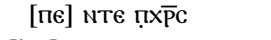 & \\
\hline [ & ] & & 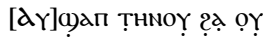 & 7.23 \\
\hline [ & ] & & [тімн м] & \\
\hline [ & ] & 40 & 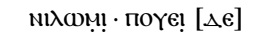 & 7.24 \\
\hline [ & ] & & $\begin{array}{l}\text { поYєı ṇạcnнoy [2M] } \\
\text { пт02єм NтаY }\end{array}$ & \\
\hline
\end{tabular}


Figure 3. The Morgan Library \& Museum, MS M.585, fol. $5 \mathrm{I}^{\mathrm{v}}+$ fol. $5 \mathrm{I}^{\mathrm{r}}$. Purchased for J. Pierpont Morgan (1837-1914) in 1911. Digitally reassembled by Ivan Miroshnikov.

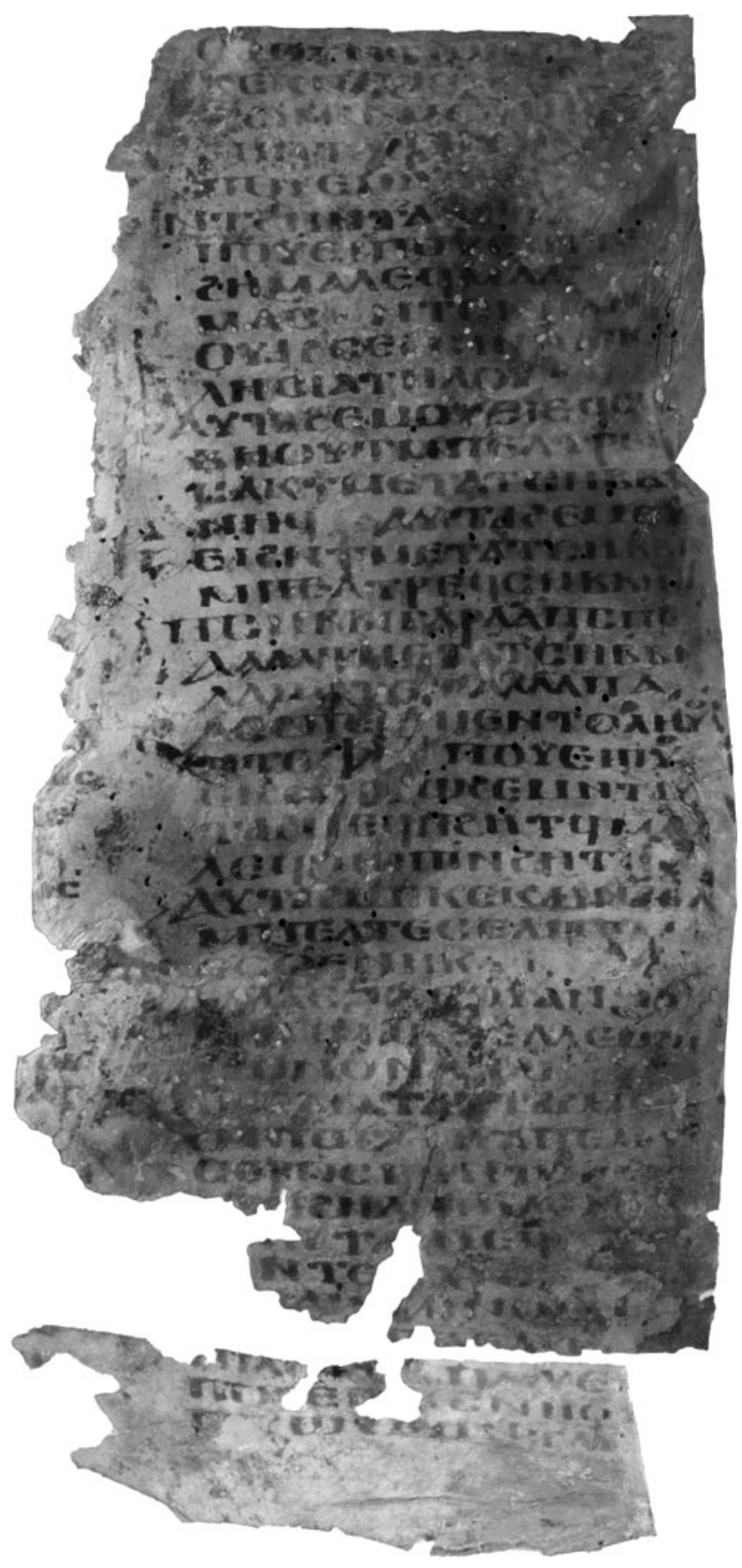


Fol. $(\mathrm{d}+\mathrm{e})^{\mathrm{v}}\left(\right.$ MS M.585, fol. $51^{\mathrm{r}}+$ fol. $51^{\mathrm{v}}$; see Fig. 4)

7.25

T2ДMеY N2HTY

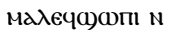

2HTY 2aTEN $\overline{\phi \dagger}$

Єтве міпарөє

NOC $\triangle E$ MNT OY

d2 ce2NI NTE $\Pi \overline{\mathrm{OC}}$

MMEY OYTNO

MH $\triangle \epsilon$ † MMAC

NT2H NNOYEl Ed

$\Pi \overline{\mathrm{OC}} \mathrm{NeEl} \mathrm{NHY}$

Кес тас)юп $\mathrm{M}$

7.26 пистос · †мн

oY rap Xe nanoY

пеl етреч()ळп

етве таNагтн ет

c)daח Xe NanoYc

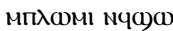

III NTEISH .

7.27 Ксан? есгімі мпє

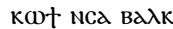

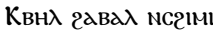

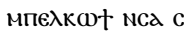

$7.28 \quad$ 2IMl $\cdot$ KaN Eल)ळா aK()ANXI NKEX Na

Bl eN $\cdot$ aYo ed)

mi acc)anXI nXe †

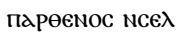
$\mathrm{NABl} \in \mathrm{EN} \cdot \mathrm{eYEXI}$

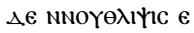
TEYCAP乏 NXE NEI NTEI2H - aNAK $\Delta \epsilon$

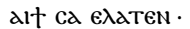

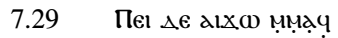
NaCNHOY Xe

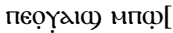
пе $\cdot$ 入оппом ке̣c NH EṬ oY[aN]

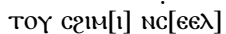
Т2H NNH [ЕTе MN]

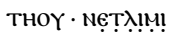

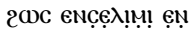

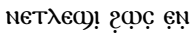

$\left.\begin{array}{lll}40 \quad[ & {[} & ] \\ & {[} & ] \\ & {[} & ]\end{array}\right]$


Figure 4. The Morgan Library \& Museum, MS M.585, fol. $5 \mathrm{I}^{\mathrm{r}}+$ fol. $5 \mathrm{I}^{\mathrm{v}}$. Purchased for J. Pierpont Morgan (1837-1914) in 1911. Digitally reassembled by Ivan Miroshnikov.

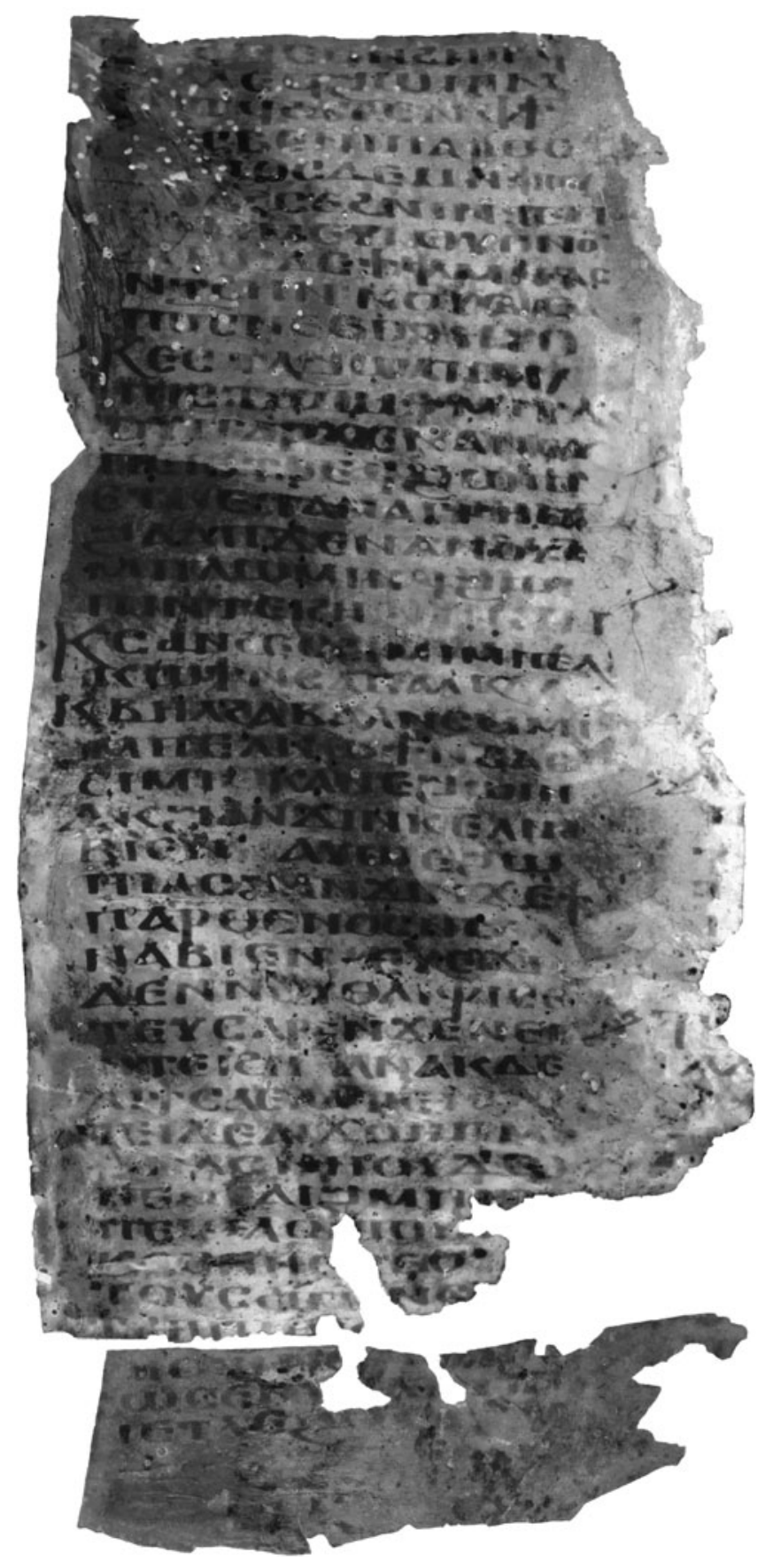


Fol. (b) ${ }^{\mathrm{r}}$ (MS M.585, fol. ii ${ }^{\mathrm{r}}$; see Fig. 5)

15.3

15.4

15.6

15.10 $x \in \pi \times \bar{p} \mathrm{c}$ дчмоү

EXEN NENNABl

каTа Nеграфн

aүo $x \in$ aүKadNCY

дүळ $x \in$ ачтонч мпегдоч мме2 $\bar{\Gamma}$

ката меграфн aYW Xe ayoYan24 eкHфd - ITA aчOY aN2Y $\mathrm{\epsilon \Pi \Pi \overline {B }} \cdot \mathrm{MN}$ coc ayoYanzY eпе gOYa nब NCAN 21 оүсап NEl єTe пеY zoYd ()גan a)d ę OYN EtNOY $\cdot 2 \mathrm{EN}$ кекаY $\Delta \epsilon$ aYeN KaT + ITd aYOYAN 24 еІакковос. M

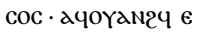
NІкедпосто入ос

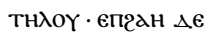
MMAY TH入OY NT $2 \mathrm{H}$ NOY2OY2H аपOY

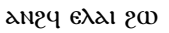
ДNак гар пє пкоҮ

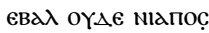

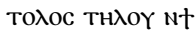
емпа)є еN етроY moYt $\epsilon \lambda a l$ Xe апос

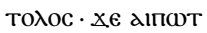
NCd TeKK入HCld N Te $\overline{\phi \dagger} \cdot 2 \mathrm{~N}$ OY2MaT

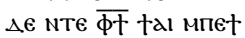
al мMач - аүळ печ 2MAT ЕTEN2HT M печо)фп! ечव)०

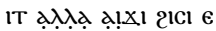
20Yalcte eגaY TH

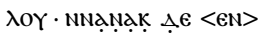

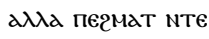

$\overline{\phi \dagger}$ етNeMH

ITE OYN ANAK ITE

NH aN2l ald) NTẹ!

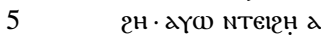

TeтеNEגחicteY!n

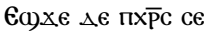

2l alc) ммач $x \in$ ay

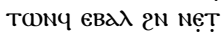

MaOYT - пळс OY aN 2aINI 2N THNộY $X 0$ MMac $X \in$ MṂN andactacic nṬe

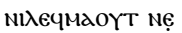

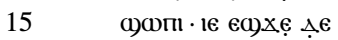
MMN ANACTACIC $\mathrm{N}$

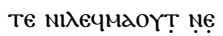
ळ) TONY - ed)Xe $\lambda \epsilon$

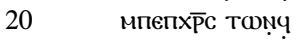
2apd q0) NiT NXE пеN2l dil) - aүy c

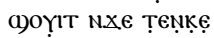
mictic $\cdot 1 €$ cene

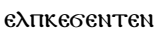
$\triangle \epsilon$ 2OON ENA! M метрH NNOYX ?a $\overline{\phi \dagger} \cdot x \in$ ane $\mathrm{MeT}$ PH 2a $\overline{\phi \dagger}$ xढ़ ạтọ

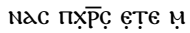
печтоҮ̣ạcy

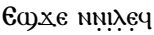

maOYT nẹṭ NoY Єn !̣ мח̣є

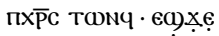

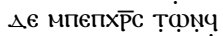
oүm6eel Tẹ Tệ חICTIC 16 ET! âN

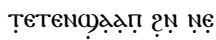




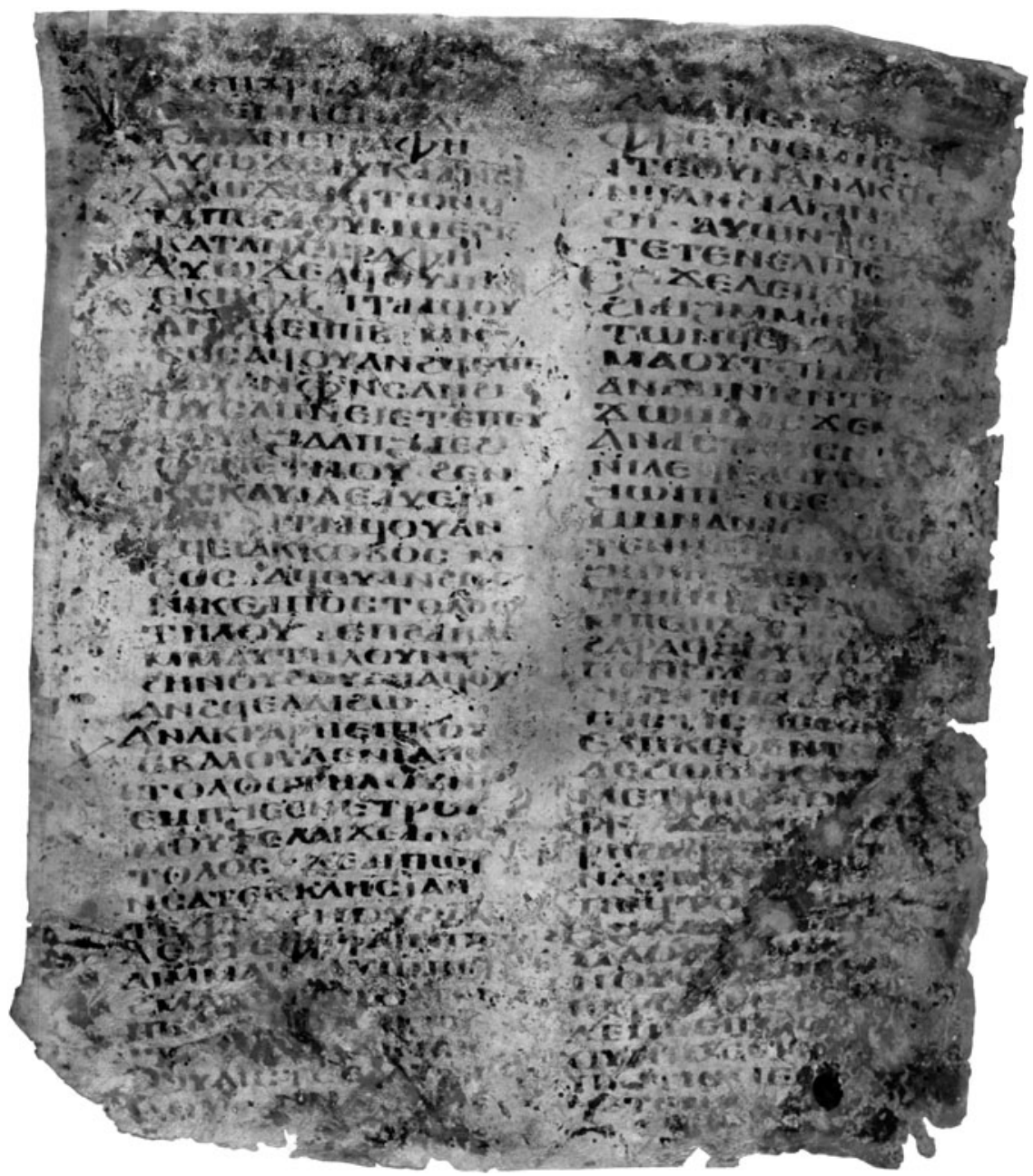

Figure 5. The Morgan Library \& Museum, MS M.585, fol. iir. Purchased for J. Pierpont Morgan (I837-1914) in 1911. 
Fol. (b) ${ }^{\mathrm{v}}$ (MS M.585, fol. ii ${ }^{\mathrm{v}}$; see Fig. 6)

15.18

15.19

15.20

15.21

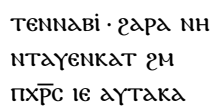

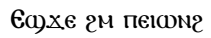
oYdeTY ane $2 \epsilon \lambda$

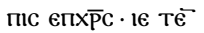

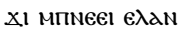

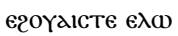
MI NIBi - tNoY $\Delta E$

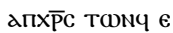
Bad 2N NeTMaOYT TAחаPXH <N>NH NTAY ENKAT. -

EпLАн гар еваג 21

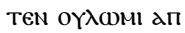

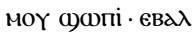

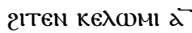
Tanactacic nTE Ni入eqMaOYT Ne

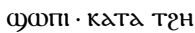
eтоYMaOYT TH

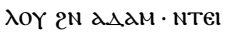
2H $2 \mathrm{M} \pi \overline{\mathrm{P} C} \mathrm{CeNe}$

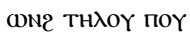
еl поүез гм печ

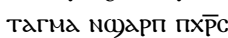

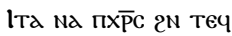
парPoYcla $\cdot$ ITa пXOK · 2OTAN aydant NTMET

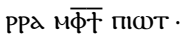
готам ачодаnоY DCY NaPXH NIBI MN EzoYcla NIBl MN GAM NIBI $2 \omega \dagger$

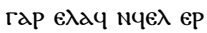
pa- a)anteqko NNEYXeXI NCa песнт NNEY

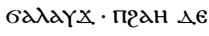

NXEXI qNeOYळCq

ете пмоү пе ач

трегов NIBl $\mathrm{e \lambda}$

5

гнпотасесөє

NCAחECHT NNeY

GaldYX NXe $\dot{\overline{\phi t}}$

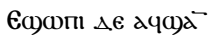

Хac $x \in$ дгов NI

10

Bl єлгнпотдZес

өє NHY - $\triangle H \lambda O N$

ФТІ мпечке $\lambda$ дпс

NNOYEQ) елгнпо

таzеceе NHY.

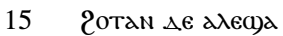

гथв NIBI є 2 гно

TazeceE NHY

Tоте NTaY го00Y

па) $\mathrm{H \lambda}$ єчєе $2 \mathrm{H}$

20

потдZесөє мпн

NTачTPєгов NI

Bl елгнпотаZес

eE NHY - 2INA N

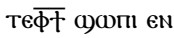

25

таY пе $\{2 \mathrm{~N}\}$ 20B NIBI

2N OYan NIBi

Emman оүм пе

ToYneely nXe

NH ЕТХОКем

30 MMAY EXEN NiגeY

MaOYT - ea)Xe

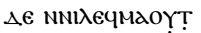

$\lambda \omega$ NeTWNOY

етве OүN сеєлп

кеХІ ХФКем є2

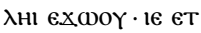

Be OYN ANAN 20

WN TEN2HC) NOY

ald) NIBI 


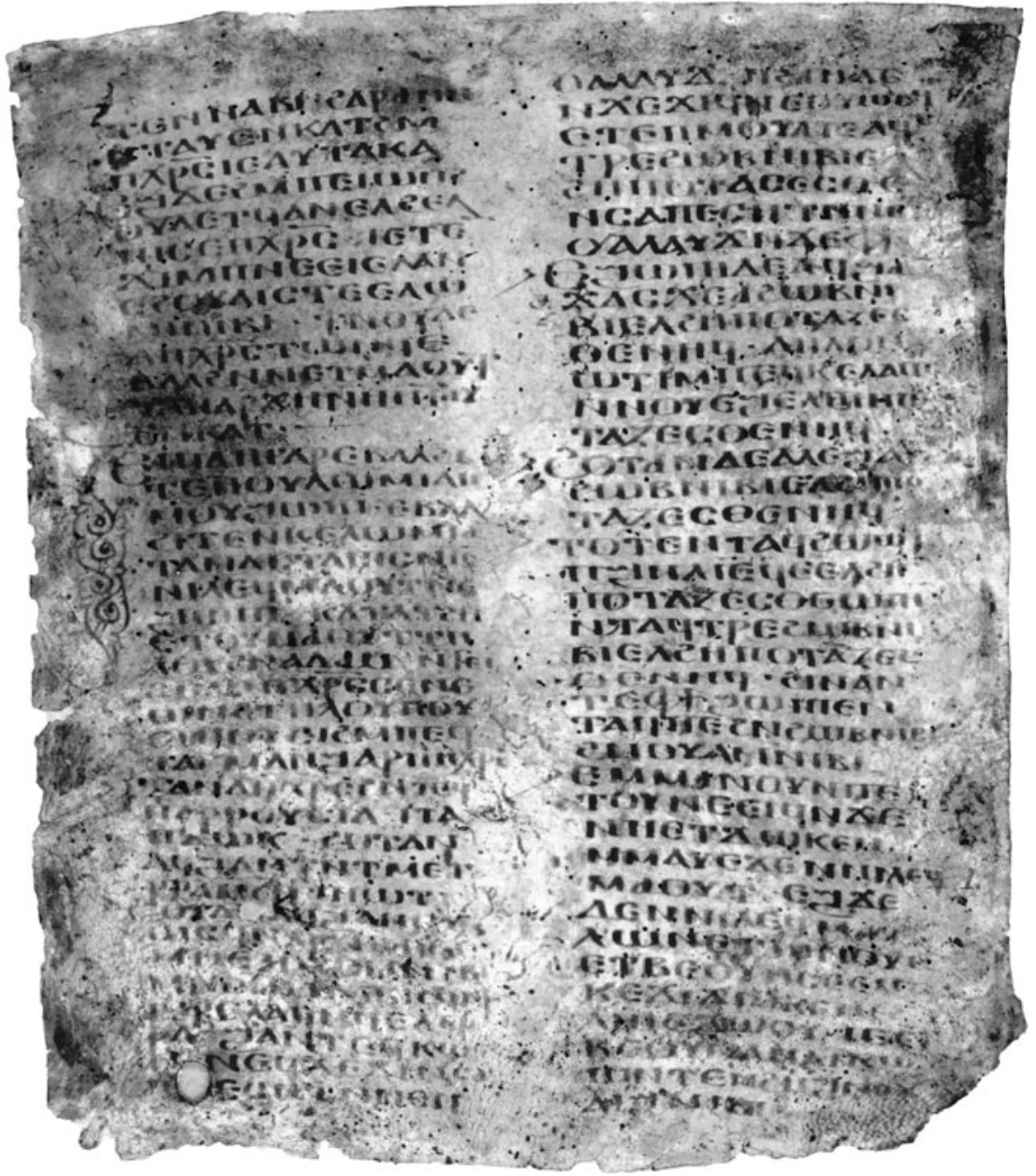

Figure 6. The Morgan Library \& Museum, MS M.585, fol. ii. Purchased for J. Pierpont Morgan (I837-1914) in 1911. 


\section{Notes on the Coptic Text}

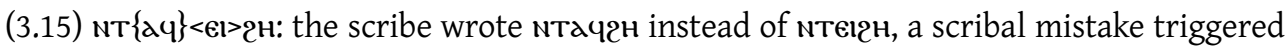
by the word NTaq, which occurs earlier in the same verse.

(7.16) caorn: the last line of the preceding leaf most certainly read [ak].

(7.24) $[\lambda \epsilon]$ : the line appears to be too short in comparison to the ones above and below, unless we supposed that a few letters were lost in the lacuna. I restore $[\lambda \epsilon]$, assuming that fa agrees with the variant reading attested in several witnesses of bo.

(7.29) мпب[: I leave the word 'withdrawal' (B5 लрч) unrestored, because it is unclear whether or not it was subject to lambdacism in F5.

$(15.10)<\in N>$ : although the text at the bottom of fol. $(b)^{r}$ is poorly legible, it seems certain that, at the end of the first column, there is no text after $\lambda \epsilon$. In all likelihood, the scribe omitted $\mathrm{eN}$ by mistake in the transition from the last line of the first column to the first line of the second column. An enticing alternative to this emendation is to suggest that NN- before ạak functions as the sole negator in this sentence - a phenomenon that, according to Wolf-Peter Funk, seems to occur in several Coptic dialects, including $M, B 4$ and $B 5{ }^{40}$ However, since this phenomenon seems to be otherwise unattested in Fayyūmic and since the parallel text of P.MorganLib. 268 does not omit $\mathrm{eN}$, I have chosen to emend the text.

(15.12) MMN | aNACTacic: only the traces of what seems to be a vertical stroke are discernible after $\boldsymbol{M}$. This vertical stroke can belong to either $\boldsymbol{M}$ or $\mathrm{N}$; thus, the manuscript may have read either mụ or mọ. Given that, in the next verse, just a few lines below, the manuscript reads MMN aNdCTacic, I have opted for the former option.

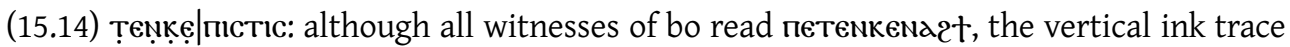
following $\mathrm{T} \in$ is compatible with $\mathrm{N}$, but not $\mathrm{T}$, which means that the manuscript could not

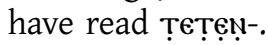

(15.17) TeN|mictıc: the ink traces at the end of line 37 are impossible to discern. However, though all witnesses of bo read пєтемNג2t, the available space seems to make the reading

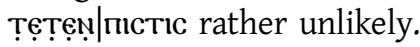

(15.20) < $>\mathrm{NH}$ : admittedly, the omission of the linkage marker $\mathrm{N}$ - may be due to 'phonetic' haplography; however, since this is the only instance of the omission of the initial morphemic $\mathrm{N}$ in this manuscript, I find it more plausible that the scribe made a mistake.

(15.28) $\{2 \mathrm{~N}\}$ : the scribe wrote the preposition $2 \mathrm{~N}$ before 2 ОВ м мв by mistake, in anticipation of the $2 \mathrm{~N}$ that occurs before oyan NIBI later in this verse.

${ }^{40}$ W.-P. Funk, 'Negative N- without aN as a Late Survival in Coptic Egyptian', JCoptS 16 (2014) 125-38. 


\section{Translation}

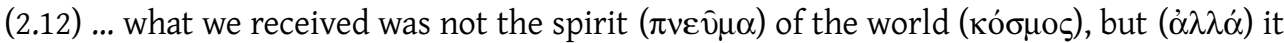
was the Spirit $(\pi v \varepsilon v \hat{\nu} \alpha)$ from God, that (iv $\alpha$ ) we might understand the things that God gave us as a gift (2.13) - these things that we speak - discerning, along with spiritual people ( $\pi v \varepsilon v \mu \alpha \tau 1 \kappa o ́ \varsigma)$, spiritual things ( $\pi v \varepsilon v \mu \alpha \tau 1 \kappa o ́ v)$, not through the human teachings of wise words but ( $\dot{\alpha} \lambda \lambda \dot{\alpha})$ through the teachings of the Spirit $(\pi v \varepsilon \hat{v} \mu \alpha)$. (2.14) Indeed ( $\delta \dot{\varepsilon})$, the psychical ( $\psi v \chi$ «ós) person never receives the things belonging to the spirit $(\pi v \varepsilon \hat{v} \mu \alpha)$ of God, for ( $\gamma \alpha \dot{\alpha} \rho)$ it is foolishness for him. And he is unable to understand, for it is discerned spiritually $(\pi v \varepsilon v \mu \alpha \tau \imath \kappa \hat{\omega} \varsigma)$. (2.15) The Spirit $(\pi v \varepsilon \hat{v} \mu \alpha)$, on the other hand $(\delta \dot{\varepsilon})$, discerns everything, but ( $\delta \dot{\varepsilon})$ it itself no one discerns. (2.16) For ( $\gamma \alpha \dot{\alpha} \rho)$ 'who has known the mind of the Lord, or who will be able to instruct him? ${ }^{41}$ As for us, on the other hand $(\delta \varepsilon \dot{\varepsilon})$, we have the mind of Christ.

(3.1) Hence ( $\delta \dot{\varepsilon})$, my brothers, I myself could not speak to you as I might speak to spiritual

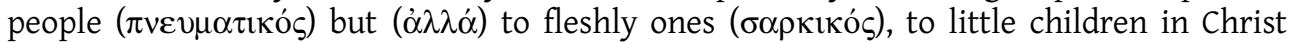
Jesus. (3.2) I gave you milk to drink - it is not food - for ( $\gamma \alpha \dot{\alpha} \rho)$ you were not yet capable. ${ }^{42}$

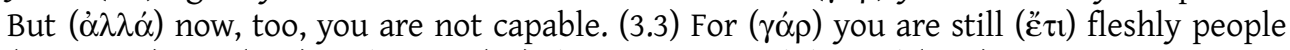

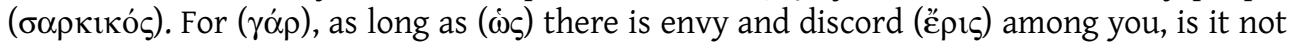

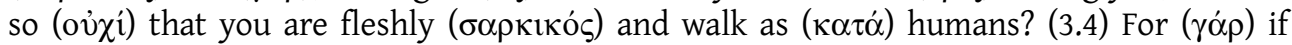
someone says, 'As for me, I, on the one hand ( $\mu \dot{\varepsilon} v)$, belong to Paul', and someone else,

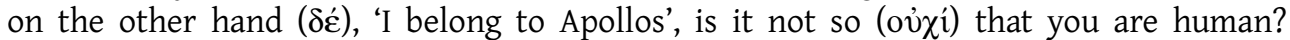

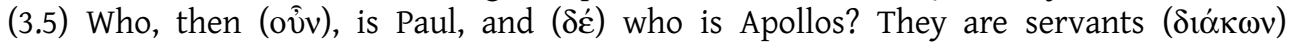

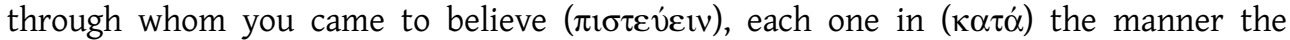
Lord assigned him. (3.6) I planted, Apollo watered, but ( $\delta \dot{\varepsilon})$ God made them grow. (3.7) Therefore $(\check{\sigma} \sigma \varepsilon)$, neither the one who plants nor the one who waters is anything, ${ }^{43}$ but ( $\dot{\alpha} \lambda \lambda \dot{\alpha})$ God, the one who causes them to grow. ${ }^{44}$ (3.8) The one who plants and the

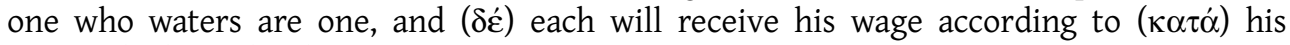
labour. (3.9) For ( $\gamma \alpha \dot{\alpha} \rho)$ we are God's fellow workers, and you, God's tillage, are God's building, (3.10) according to ( $\left.\alpha \tau \tau_{\alpha}\right)$ the grace of God given to me. Like a wise master-builder

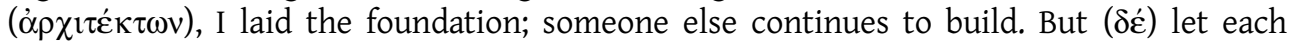
one pay heed to how he builds. (3.11) For ( $\gamma \alpha \dot{\alpha} \rho)$ it is impossible for someone else to lay a foundation other than ( $\pi \alpha \rho \alpha$ ) the one that is laid down - namely, Jesus Christ. (3.12) If there is someone who continues to build on this foundation with gold, silver, precious stones, wood, hay or straw, (3.13) the work of each one will be revealed. For ( $\gamma \alpha \dot{\alpha} \rho)$ the day will reveal [him], ${ }^{45}$ because it ${ }^{46}$ will be disclosed in fire, and the fire is what will assay

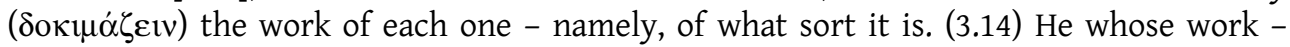
which he built - will remain, will receive his wage. (3.15) He whose work will burn, will lose it. Yet $(\delta \dot{\varepsilon})$ he himself will be saved but (ov̂v) in <this> way: through fire. (3.16) Do you not know that you are a temple of God and that the Spirit ( $\pi v \varepsilon v \mu \alpha)$ of God dwells in you? (3.17) He, then (ovv), who will defile the temple of God will be

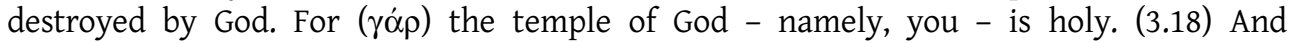

\footnotetext{
${ }^{41}$ Isa 40.13 .

${ }^{42}$ Here, as well as in the next sentence, the translator retained the elliptic structure of the Greek sentence (the reader is supposed to supply something along the lines of 'of digesting real food').

${ }^{43}$ Literally, 'the one who plants and the one who waters are nothing'.

${ }^{44}$ The translator retained the elliptic structure of the Greek sentence (the reader is supposed to supply something along the lines of 'is everything').

${ }^{45}$ That is, each one.

${ }^{46}$ That is, the work.
} 
(ov̂v) let no one deceive himself. He who thinks among you ...

(7.16) ... how [do you] know, husband, that you will be able to save your wife, (7.17) except the way God appointed each one? Just as God called each one, so let him walk. And so also

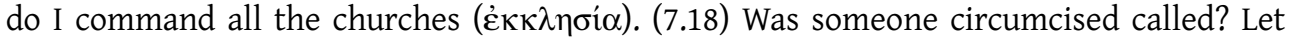
him not draw out his uncircumcision. ${ }^{47}$ Was someone uncircumcised called? Let him not circumcise himself. (7.19) For ( $\gamma \dot{\alpha} \rho)$ circumcision is nothing, but ( $\dot{\alpha} \lambda \lambda \dot{\alpha})$ uncircumcision is (also) nothing. Rather ( $\dot{\alpha} \lambda \lambda \dot{\alpha})$, it is the observance of God's commandments $\left(\dot{\varepsilon} v \tau \mathrm{\nu} \lambda \hat{\eta}^{4}{ }^{48}\right.$ (7.20) Let each one be in the calling to which he was called. (7.21) Were you called while being a slave? Let it not be a concern ( $\mu \dot{\varepsilon} \lambda \varepsilon \sigma \theta \alpha \mathrm{l})$ for you. But ( $\dot{\alpha} \lambda \lambda \dot{\alpha})$ if you can become free, do only ( $\mu$ óvov) this. (7.22) A slave who was called in the Lord is the Lord's freedman ( $\dot{\alpha} \pi \varepsilon \lambda \varepsilon v \dot{\theta} \theta \varepsilon \rho \varsigma \varsigma)$. So also a free individual who was called [is] a slave of Christ. (7.23) [You were] bought with a [price ( $\left.\tau \mu \eta^{\prime}\right)$ ]; do not become slaves of humans. (7.24) [And ( $\delta \dot{\varepsilon})$ ] let each one, my brothers, be with God [in] the calling to which he was called. (7.25) Now $(\delta \dot{\varepsilon})$, concerning virgins ( $\pi \alpha \rho \theta \dot{\varepsilon} v \varsigma_{\text {) }}$, I have no commandment of the Lord, ${ }^{49}$ but ( $\left.\delta \dot{\varepsilon}\right)$ I give an opinion $(\gamma v \omega \dot{\mu} \mu)$ as someone on whom the Lord had pity, so that I became faithful ( $\left.\pi 1 \sigma \tau \sigma_{\varsigma}\right)$ ). (7.26) For ( $\left.\gamma \alpha \dot{\alpha} \rho\right)$ I think that it is good for this to be so ${ }^{50}$ because of the present distress ( $\dot{\alpha} v \alpha \dot{\alpha} \kappa \eta)$, that it is good for man to be this way. (7.27) Are you bound to a wife? Do not seek to untie yourself. Are you untied from a wife? Do not seek a wife. (7.28) Even if (אöv) you should marry, you do not sin. And if a virgin ( $\pi \alpha \rho \theta \varepsilon \dot{v} \vee \varsigma)$ marries, she does not sin. But $(\delta \varepsilon \dot{)})$ people of such a sort shall receive affliction

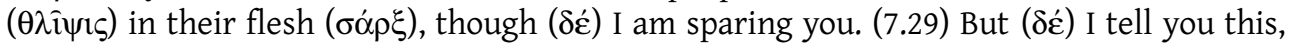
my brothers: it is the time of [withdrawal], so that henceforth ( $\lambda$ ouróv) those who have wives ought to [be] like those [who] do [not]; (7.30) those who weep as though ( $\dot{\omega} s)$ not weeping, those who rejoice as though (ís) not ...

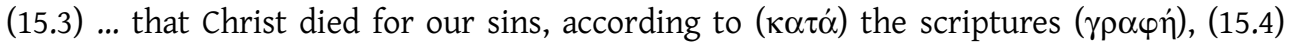

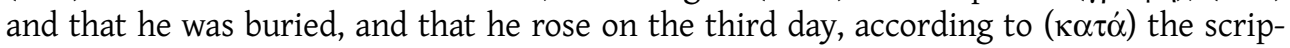
tures $\left(\gamma \rho \alpha \varphi \eta^{\prime}\right),(15.5)$ and that he appeared to Cephas, then ( $\left.\dot{i} \tau \alpha\right)$ he appeared to the twelve. (15.6) Then he appeared to more than 500 brothers at once, of whom the most remain until now, while ( $\delta \dot{\varepsilon})$ others have fallen asleep. ${ }^{51}(15.7)$ Then $(\varepsilon \hat{i} \tau \alpha)$ he appeared

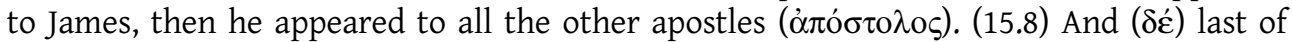
all, like to an untimely birth, he appeared to me, too. (15.9) For ( $\gamma \alpha \dot{\alpha} \rho)$ I am the least of

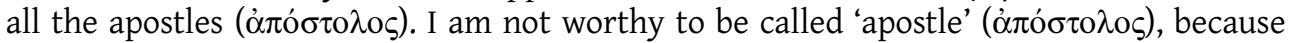

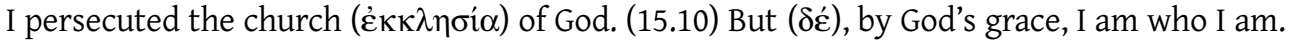
And his grace, which is in me, has not become empty, but ( $\dot{\alpha} \lambda \lambda \dot{\alpha})$ I toiled more than all of them - though ( $\delta \dot{\varepsilon})$ not I, but ( $\dot{\alpha} \lambda \lambda \dot{\alpha})$ the grace of God which is with me. (15.11) Whether

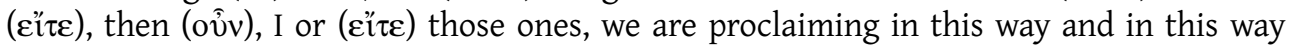

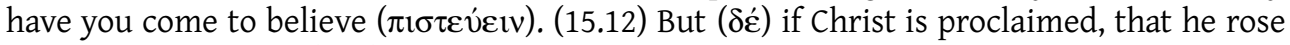
from the dead, how $(\pi \hat{\omega} s)$ is it that some of you say that there will be no resurrection ( $\dot{\alpha} v \alpha \sigma \tau \alpha \sigma \iota \varsigma)$ of the dead? (15.13) And ( $\delta \dot{\varepsilon})$, therefore, if there should be no resurrection ( $\dot{\alpha} v \alpha \sigma \tau \alpha \sigma \iota \varsigma)$ of the dead, then Christ did not rise. (15.14) And ( $\delta \dot{\varepsilon})$ if Christ did not rise, then ( $\not \rho \alpha)$ our proclamation is empty, and our faith ( $\pi i \sigma \tau \iota)$ is also empty. (15.15) And $(\delta \dot{\varepsilon})$, therefore, we ourselves will also be found false witnesses against God, because we

\footnotetext{
${ }^{47}$ That is, he should not pull his foreskin over to conceal his circumcision. The word 'uncircumcision' is added by the translator in an attempt to elucidate the technical meaning of $\dot{\varepsilon} \pi \mathrm{\imath} \sigma \hat{\alpha} \sigma \theta \alpha \mathrm{l}$ ('to drag up').

${ }^{48}$ The translator retained the elliptic structure of the Greek sentence (the reader is supposed to supply something along the lines of 'that matters').

${ }^{49}$ Or, 'from the Lord', if NTE- is a variant spelling of NTEN- 'from'.

${ }^{50}$ That is, it is good to remain a virgin.

${ }^{51}$ That is, they have died (so also verses 18 and 20 below).
} 
bore witness to God, that he raised Christ, whom he did not raise. (15.16) If the dead should not rise, then Christ did not rise. (15.17) And ( $\delta \dot{\varepsilon})$ if Christ did not rise, our

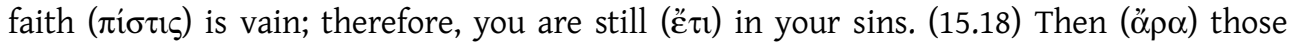
who have fallen asleep in Christ have perished. (15.19) If it is only in this life that we

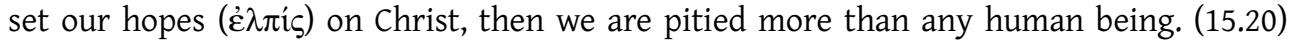
But $(\delta \dot{\varepsilon})$, now, Christ rose from the dead, the first fruits ( $\left.\dot{\alpha} \pi \alpha \rho \chi \eta^{\prime}\right)<o f>$ those who have fallen asleep. (15.21) For ( $\gamma \dot{\alpha} \rho)$ since ( $\dot{\varepsilon} \varepsilon \varepsilon 1 \delta \dot{\eta})$ death happened through a man, the resur-

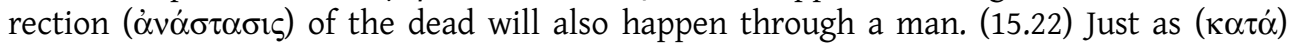
they are all dead in Adam, so also will they all live in Christ, (15.23) each one in his order $(\tau \alpha \dot{\gamma} \gamma \alpha)$ ): first Christ, then $(\varepsilon i \tau \alpha)$, at his coming ( $\pi \alpha \rho o v \sigma i \alpha)$, those who belong to Christ. (15.24) Then ( $\varepsilon i \tau \alpha)$ (comes) the end, after (ö $\alpha v$ ) he has delivered the kingdom to God the Father. After (ö $\tau \alpha \nu)$ he has destroyed every rule ( $\dot{\alpha} \rho \chi \eta)$ ), and every authority ( $\left.\dot{\varepsilon} \xi_{0} \sigma^{\prime} \alpha\right)$, and every power, (15.25) indeed ( $\left.\gamma \alpha \dot{\alpha} \rho\right)$, he must reign until he has put his enemies under his feet. (15.26) And ( $\delta \dot{\varepsilon})$ the last enemy will be destroyed - namely, death. (15.27) 'God made everything be subject (i $\pi 0 \tau \alpha \sigma \sigma \varepsilon \sigma \theta \alpha \mathrm{l}$ ) under his feet." And ( $\delta \dot{\varepsilon})$ if he ${ }^{53}$ says that everything became subject (i $\pi$ o $\alpha \dot{\alpha} \sigma \sigma \varepsilon \sigma \theta \alpha \mathrm{l}$ ) to him, ${ }^{54}$ it is evident

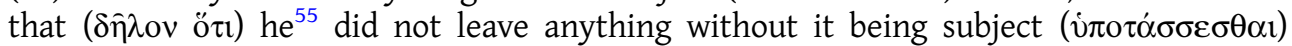

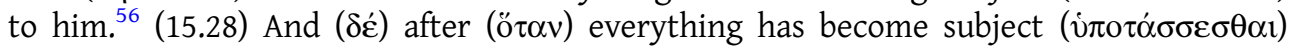
to him, then ( $\tau$ ó $\tau$ ) he himself, the Son, shall become subject (i $\pi \mathrm{o} \tau \dot{\alpha} \sigma \sigma \varepsilon \sigma \theta \alpha \mathrm{l}$ ) to the one who made everything be subject (i $\pi \mathrm{o} \tau \alpha \sigma \sigma \varepsilon \sigma \theta \alpha \mathrm{l}$ ) to him, so that (iv $\alpha$ ) God might be everything in everyone. (15.29) Otherwise, what will those who are baptised with water for the dead do? Indeed $(\delta \dot{\varepsilon})$, if the dead should never rise, why do they receive baptism for them ${ }^{57}$ also? (15.30) Then why are we ourselves always in distress? ...

Competing interests. The author declares none.

\footnotetext{
${ }^{52}$ Ps 8.7.

${ }^{53}$ That is, David.

${ }^{54}$ That is, Jesus Christ.

55 That is, God.

${ }^{56}$ That is, Jesus Christ.

${ }^{57}$ That is, the dead.
}

Cite this article: Miroshnikov I (2022). A New Witness to the Fayyūmic Version of First Corinthians (P.MorganLib. 265). Part II: Notes on its Text-Critical Value, with an Edition of the Coptic Text. New Testament Studies 68, 206-230. https://doi.org/10.1017/S0028688521000357 